\title{
Challenges for the Transition to Low-Temperature Heat in the UK: A Review
}

\author{
Antoine Reguis * $\mathbb{0}$, Behrang Vand $(\mathbb{D}$ and John Currie
}

check for

updates

Citation: Reguis, A.; Vand, B.; Currie, J. Challenges for the Transition to Low-Temperature Heat in the UK: A Review. Energies 2021, 14, 7181.

https://doi.org/10.3390/en14217181

Academic Editor: Susan Krumdieck

Received: 31 August 2021

Accepted: 21 October 2021

Published: 2 November 2021

Publisher's Note: MDPI stays neutral with regard to jurisdictional claims in published maps and institutional affiliations.

Copyright: (c) 2021 by the authors. Licensee MDPI, Basel, Switzerland. This article is an open access article distributed under the terms and conditions of the Creative Commons Attribution (CC BY) license (https:/ / creativecommons.org/licenses/by/ $4.0 /)$.
School of Engineering and the Built Environment, Edinburgh Napier University, Edinburgh EH10 5DT, UK; b.vand@napier.ac.uk (B.V.); j.currie@napier.ac.uk (J.C.)

* Correspondence: a.reguis@napier.ac.uk

\begin{abstract}
To reach net-zero emissions by 2050, buildings in the UK need to replace natural gas boilers with heat pumps and district heating. These technologies are efficient at reduced flow / return temperatures, typically $55 / 25^{\circ} \mathrm{C}$, while traditional heating systems are designed for $82 / 71{ }^{\circ} \mathrm{C}$, and an oversized heating system can help this temperature transition. This paper reviews how heating systems have been sized over time in the UK and the degree of oversizing in existing buildings. It also reviews if lessons from other countries can be applied to the UK's building stock. The results show that methods to size a heating system have not changed over time, but the modern level of comfort, the retrofit history of buildings and the use of margin lead to the heating system being generally oversized. It is not possible to identify a specific trend by age, use or archetype. Buildings in Scandinavia have a nascent readiness for low-temperature heat as they can use it for most of the year without retrofit. Limitations come primarily from the faults and malfunctions of such systems. In the UK, it is estimated that $10 \%$ of domestic buildings would be ready for a supply temperature of $55^{\circ} \mathrm{C}$ during extreme external conditions and more buildings at part-load operation. Lessons from Scandinavia should be considered with caution. The building stock in the UK generally underperforms compared to other EU buildings, with heating systems in the UK operating at higher temperatures and with night set-back; the importance of providing a low-return temperature does not exist in the UK despite being beneficial for condensing boiler operation. Sweden and Denmark started to develop district heating technologies with limitations to supply temperatures some 40 years ago whereas the UK is only just starting to consider similar measures in 2021. Recommendations for policy makers in this context have been drawn from this review in the conclusions.
\end{abstract}

Keywords: low-temperature heat; district heating; 4th generation district heating; sizing and oversizing heating system

\section{Introduction}

Buildings play a significant role in fulfilling the UK's commitment to the Paris Agreement [1] decided within the United Nations Framework Convention on Climate Change (UNFCCC). For example, Scotland has set its own indicative National Determined Contribution (NDC) to reduce greenhouse gas emissions by at least $75 \%$ before 2030 compared to 1990. In addition, Scotland aims to reach net-zero emissions by 2045 instead of the general 2050 UK target $[2,3]$.

In 2019, space heating (SH) represented 61\% of the heat consumption in the UK and $28 \%$ of total energy use [4]. For the building sector, all buildings need to be net-zero, and this should be achieved by energy efficiency measures and a move away from fossil fuel, which currently supplies $90 \%$ of the heat demand [5]. In its vision for 2050, the Committee on Climate Change [6] projects that fossil fuels will be replaced by heat pumps $(52 \%)$, low-carbon heat networks in heat-dense areas such as cities (42\%), "potentially" hydrogen boilers (5\%) and direct electric heating (1\%). For heat networks, public buildings would be used as anchor loads. Heat pumps and low carbon technologies are efficient 
at reduced operating temperatures, and the new emerging standard for low-temperature heat, namely, 4th Generation District Heating (4GDH), is 55/25 ${ }^{\circ} \mathrm{C}$ for flow / return [7]. As heating systems in the UK are usually designed to operate at $82 / 71^{\circ} \mathrm{C}$, this raises the question of the ability of existing buildings to use such technologies and how existing systems are designed and perform. The efficiency of existing heating systems is often limited due to oversizing. Oversizing generates losses in efficiency, reduces equipment life span, reduces comfort for occupants, increases capital and operating costs and limits the ability to reach $\mathrm{CO}_{2}$ reduction targets. Oversizing is a widespread problem across the built environment [8] and can affect the heating plant, heat emitters, distribution circuits or the control of hydraulic circuits. Oversizing can occur at the design stage, construction phase or due to changes in the retrofit history of the building. These limitations to reach expected performances can question the ability of the construction sector to deliver net-zero buildings [9]. However, oversizing also has positive benefits as it can facilitate the transition to reduced temperatures. In the UK, the concept of a low-temperature DH system is rarely used as the heat is largely provided by gas boilers, and DH supplies only $2 \%$ of the heat demand [10]. Meanwhile, some countries have initiated a move towards heating system temperature reduction, mainly where $\mathrm{DH}$ is widely deployed, initially to maintain the business model in a context of heat demand contraction and lately to decarbonise their heating system.

This paper is structured in three sections, following the introduction in Section 1. Section 2 aims to review how existing space heating systems have been sized over time in the UK. It also reviews the definitions, drawbacks, origins, magnitude and benefits of oversizing and methods to evaluate the oversizing of space heating systems. Section 3 aims to review the system operating temperatures commonly used in the UK and abroad. Section 3 also reviews the benefits and challenges of low-temperature heat, the ability of existing buildings to use reduced operating temperatures and the role energy efficiency measures have when combined with various degrees of oversizing of heating systems. A review of experiences drawn from other countries, especially in Denmark and Sweden, is carried out to understand if or how lessons from abroad can be applied in the UK.

\section{Sizing and Oversizing of Heating System}

\subsection{Sizing of Heating Systems}

Most current buildings and their heating systems were designed and built a number of years ago. This is especially true in the UK, as it has the oldest housing stock in Europe, with much of it still dating from the industrial revolution [11]. Past retrofit measures may have changed the primary fuels used to service the building (e.g., coal replaced by oil, then by gas), but many heat distribution components and terminal units might remain in place and form part of the current heating systems. This section reviews the guidance provided over time by the Institute of Heating and Ventilating Engineers (IHVE), now CIBSE, and other guidebooks used by the Mechanical and Electrical (M\&E) service industry in the UK, where the first form of guidance to size heating systems was published as a loose-leaf volume in 1940 [12]. This was revised and published as a first bound volume in 1955 [12], and from then on updated editions were published in 1965, 1970, 1986, 2006 and 2016 [13-17]. A heating system aims to provide heat for SH and Domestic Hot Water (DHW). While it was historically general practice to add capacity to a boiler for DHW, since the early 1970s, this is deemed unnecessary [14,18]. In most cases, DHW demand can be met by diverting capacity from the heating circuit for a short period $[17,18]$. Therefore, the scope of this article is limited to the sizing of heating system for $\mathrm{SH}$ only.

\subsubsection{Design Conditions}

Sizing a heating system has traditionally taken the following steps: (i) the identification of external design and internal design comfort conditions, (ii) the evaluation of heat load under steady-state mode without internal heat gains or solar gains and (iii) the eventual application of a pre-heat factor for intermittent use. 
Back in 1955, the recommendation was to size the system for an external design temperature of $-1.1^{\circ} \mathrm{C}$ if the heating system had a boiler with an overload capacity of $20 \%$, which was considered normal. Choosing a lower external design temperature was advised for specific situations such as avoiding discomfort during cold spells or for a system without overload capacity and for lightweight structure buildings. No specific guidance on the values to apply was given for these specific situations. The impact of thermal mass on the choice of the external design temperature was formally introduced in 1965, with heavyweight buildings being "multi-storey buildings with solid intermediate floors and partitions" and light-weight buildings being "single-storey buildings" [13]. This led to a new range of external design temperatures of between $-2.8^{\circ} \mathrm{C}$ and $-1.1{ }^{\circ} \mathrm{C}$. These values were then reduced by approximately $2.5^{\circ} \mathrm{C}$ for systems without overload capacity [13]. In 1986, a regionalisation of climatic data was recommended using specific external design temperature for eight cities across the UK. The values ranged from $-2{ }^{\circ} \mathrm{C}$ for Plymouth to $-5^{\circ} \mathrm{C}$ for Edinburgh. Lightweight construction buildings received a further temperature reduction of $1{ }^{\circ} \mathrm{C}$ [15] or $2{ }^{\circ} \mathrm{C}$ [19] and even a further reduction of $2.5^{\circ} \mathrm{C}$ for heating systems installed without overload capacities. In 2006, specific external design temperatures were removed from CIBSE Guide A and replaced with a range of values from which the appropriate temperature could be selected after discussion with the client. Other guidebooks such as BSRIA's "Rules of thumb" suggested external design temperatures of $-4{ }^{\circ} \mathrm{C}$ to $-1{ }^{\circ} \mathrm{C}$ depending on the building type and the boiler's overcapacity in 1988 [20] and has used a fixed $-4^{\circ} \mathrm{C}$ for all buildings since 2011 [21]. The influence of other factors such as geospatial data on the external design temperature was investigated by $[12,19]$. In 2019, regionalisation was improved (14 climate stations), and the table to choose for the external design temperature was based on outdoor temperature values exceeded for $99.6 \%$, $99 \%, 98 \%$ and $95 \%$ of the year.

Over the past decades, recommendations for internal design temperature have also significantly evolved. For example, in 1955, the internal temperature was expected to be $15.6^{\circ} \mathrm{C}$ in a school classroom and $10^{\circ} \mathrm{C}$ in domestic bedrooms, and these values have been increased to $19-21^{\circ} \mathrm{C}$ since 2006 (Table 1). This increase is evaluated by spot measurement data, which showed that indoor temperatures increased by $1.3^{\circ} \mathrm{C}$ per decade between 1978 and 1996 [22].

Table 1. Internal design temperatures through time in the UK (IHVE, 1955, 1965, 1970; CIBSE, 1986, 2006, 2019).

\begin{tabular}{cccccccc}
\hline Building Type & Internal Design Temperature ${ }^{\circ} \mathrm{C}$ & $\mathbf{1 9 5 5}$ & $\mathbf{1 9 6 5}$ & $\mathbf{1 9 7 0}$ & $\mathbf{1 9 8 6}$ & $\left.\mathbf{2 0 0 6} \boldsymbol{*}^{* * *}\right)$ & $\mathbf{2 0 1 9}$ \\
\hline \multirow{2}{*}{ Domestic } & Living room & $18.3^{\circ} \mathrm{C}$ & $18.3^{\circ} \mathrm{C}$ & $21^{\circ} \mathrm{C}$ & $21{ }^{\circ} \mathrm{C}$ & $19^{\circ} \mathrm{C}\left(22-23^{\circ} \mathrm{C}\right)$ & $22-23^{\circ} \mathrm{C}$ \\
& Bedroom & $10.0^{\circ} \mathrm{C}$ & $15.6^{\circ} \mathrm{C}$ & $18^{\circ} \mathrm{C}$ & $18{ }^{\circ} \mathrm{C}$ & $19^{\circ} \mathrm{C}\left(17-19^{\circ} \mathrm{C}\right)$ & $17-19^{\circ} \mathrm{C}$ \\
\hline \multirow{3}{*}{ Non-domestic } & Office (sedentary work) & $18.3^{\circ} \mathrm{C}$ & $18.3^{\circ} \mathrm{C}$ & $19^{\circ} \mathrm{C}$ & $20^{\circ} \mathrm{C}$ & $19^{\circ} \mathrm{C}\left(21-23^{\circ} \mathrm{C}\right)$ & $19-21^{\circ} \mathrm{C}$ \\
& Classroom & $16.6^{\circ} \mathrm{C}$ & $18.3^{\circ} \mathrm{C}$ & $18{ }^{\circ} \mathrm{C}$ & $18{ }^{\circ} \mathrm{C}$ & $19^{\circ} \mathrm{C}\left(19-21^{\circ} \mathrm{C}\right)$ & $19-21^{\circ} \mathrm{C}$ \\
& Assembly hall & $15.6^{\circ} \mathrm{C}$ & $18.3^{\circ} \mathrm{C}$ & $18{ }^{\circ} \mathrm{C}$ & $18{ }^{\circ} \mathrm{C}$ & $19^{\circ} \mathrm{C}\left(19-21^{\circ} \mathrm{C}\right)$ & $19-21^{\circ} \mathrm{C}$ \\
\hline
\end{tabular}

${ }^{*}$ Heating system should be sized to provide an operative temperature of $\left.19{ }^{\circ} \mathrm{C} .{ }^{* *}\right)$ Recommended $\mathrm{T}^{\circ}$ : Achieving the comfort temperature should rely on internal or solar heat gains.

This illustrates that human comfort levels and the expected capacity of heating systems have evolved to meet heat demand at various external or internal design conditions.

\subsubsection{Intermittent vs. Continuous Heating}

Intermittent heating is the most common form of operation of heating systems in the UK [17]. It is a way to reduce heat losses at night when a building is unoccupied, but this leads to a degree of overload capacity required to warm-up the building in the morning. This overload capacity is defined in the literature as the pre-heat factor, preload factor, intermittent factor, additional capacity, plant ratio, plant size ratio, boost margin or oversizing factor. In 1965, intermittent heating was expected to provide energy savings of $25-30 \%$, eventually up to $50 \%$ for lightweight structures, but only $10 \%$ for heavy buildings [13]. Short pre-heat times, while providing the most significant energy savings, may induce discomfort to occupants with warm air temperatures but cold walls/surfaces 
reducing mean radiant heat [13]. This was not accepted in some countries, for example, the USA and Germany, to allow short pre-heat and associated overload capacity [23].

The calculation of the steady-state heat load is well-established and documented in design literature, but the determination of a pre-heat factor for intermittent operation is subject to interpretations and appreciation by designers and clients [24]. In addition, it can be noted that guidelines to size the plant and the radiators for an intermittent operation has varied over time. In 1943, Faber and Kell recommended that intermittent heating operation add $10-25 \%$ to the initial standard overload capacity of $25 \%$ and all boilers should have a margin of 33\%-50\% to avoid the boiler running at full load [25]. In 1965, recommendations for pre-heat factors were around $25 \%$ [13], but it was acknowledged that it was not possible to present an easy means to determine the optimum size. In 1970, a table was provided with values for pre-heat factors ranging from $20 \%$ to $200 \%$ depending on the pre-heat time expected and the thermal mass of the building. This table was still in use in 1986 [15], while plant pre-heat factor over $25 \%$ was deemed unlikely to be justified. This table disappeared in the 2006 edition of CIBSE Guide A [16] but was still in use in a guidebook as recent as 2015 [19]. For CIBSE, since 2006, the determination of the pre-heat factor should be carried out by building simulation models, and a minimum value of $20 \%$ is advised. In 2016, a maximum value of 100\% was introduced [17]. Since 2013 in England and 2015 in Scotland, the intermittency factor for boiler design and sizing should be limited to 15 to $20 \%[26,27]$.

The overall size of the heating plant is also affected by the final choice of plant configuration to enable backup capacities [28]. The traditional approach is to install two boilers with $67 \%$ of the design condition each, at steady-state, leading to an overall plant ratio of 1.33. This provides both overload and redundancy capacity [29]. Additional capacity to deal with equipment failure should only be used when the risk of boiler failure is greater than the risk/cost of overcapacity (e.g., hospitals) [29]. It is worth noting that a diversity factor does not apply to the pre-heat period as the heat load is the sum of the heat demand for each individual room. In case of continuous operation, the size of the boiler plant can be reduced by a diversity factor of 0.7 to 1 to reflect to differences in the peak load for each room or zone of a building [17].

The overload capacity, as discussed above, applies to the boiler's capacity in the plant room and not necessarily to the heat emitters. The recommendations for the capacity of the emitting system, mostly radiators, have also varied over time. The oversizing of the emitters can be inferior to the oversizing of the central plant, as some other factors can provide an oversizing effect. An increased emitter output can be achieved because of initial low air temperature by using higher flow temperatures from the oversized central plant $[13,25]$, with the reduction in the ventilation rate in the pre-heat mode and, finally, by reducing the heat losses at night by closing curtains [15]. The only exception here was in 1970, when guidelines for the efficient thermostatic control of room temperature required that the available output from the radiator should be at all times significantly larger than the heat load, with ratios between 1.5 and 3.0 [14]. This guidance disappeared in the following edition of the CIBSE guide A [15]. In addition, other publications highlighted that the oversizing of emitters should be limited to $10 \%[19,23]$. This leads to the conclusion that the emitting system might not be as oversized as the central plant, except for a period between 1970 and 1986, where significant oversizing of radiators might have occurred. Before 1970, exposed pipes were potentially considered as an entire part of the heating system with output capacities for uncovered, freely exposed steel pipes ranging from $69 \mathrm{~W} / \mathrm{m}$ for the smallest pipe diameter $(1.27 \mathrm{~cm}$ or $1 / 2$ inches) to $740 \mathrm{~W} / \mathrm{m}$ for the largest ones $(30.48 \mathrm{~cm}$ or 12 inches) for a temperature difference of $50{ }^{\circ} \mathrm{C}$ [13].

The current situation is that the development of highly insulated buildings questions the pertinence of intermittent heating [30] as night setback in low energy buildings only moves some heat loads from the night to the morning time. This increases the need for extra capacity for the pre-heat time without providing energy savings. Hence, well-insulated buildings can operate with low temperature heat but continuous operation of the system. 
Intermittency remains to be advised for buildings with high heat load and short time constants due to poor insulation and leaky building envelopes [31] and more generally for poorly insulated buildings [30].

Finally, the current operation of the heating system can be impacted by emerging requirements such as the development of DH schemes in the UK combined with the need to deliver flexibility to the power system. DH design needs to avoid peak load as the cooccurrence of sudden morning peak demand leads to peaks in the DH system that can be problematic for utility companies [32]. This increases the need to operate heating systems in a continuous mode, while this is rarely used in UK dwellings. For large buildings, optimum start/stop control is the established practice and already provides peak shaving and continuous heating in colder periods [33]. The need to provide flexibility to the power system by shifting electricity demand away from peak hours will rely on the use of the pre-heat operation of heating systems and the building's thermal mass [6]. This will introduce new parameters in the operation of heating systems with new drivers such as the fluctuating cost of energy and the fluctuating carbon intensity of energy supplies.

\subsection{Oversizing of Heating Systems}

This section reviews the oversizing of space heating systems in its definitions, drawbacks, benefits, magnitude, origins and the methods mostly used to measure it.

\subsubsection{Definitions}

An oversized system is the result of a combination of factors occurring at various stages of the construction process [8]. Various definitions are given for oversized systems. It can be "The extent to which a parameter value exceeds what it needs to meet its functional requirements regardless of the motivation for which the margin was included" [34]. Other definitions are given by [8] as "an amount allowed beyond what is needed," or an "allowance for contingencies". An oversized plant is defined as a plant with maximum operational duty greater than that required [35]. An oversizing factor (OF) is advised to quantify the level of oversizing, and an oversizing factor of 1 is defined as a plant with ideal capacity sized for steady-state conditions at design condition [35], expressed as follows:

$$
\mathrm{OF}=\frac{\text { Installed capacity }(\mathrm{W})}{\text { Heat load at steady state design condition }(\mathrm{W})}
$$

As a heating system might have been sized years ago in existing buildings, [36] highlights that the definition of over-dimensioning requires a definition of the standard dimensions. It can be oversized for the actual operation conditions, the dimensioning standards current at the time of the building's erection or else compared to today's dimensioning standards.

\subsubsection{Drawbacks}

This section reviews the list of drawbacks identified in the literature:

- Overheating and comfort

If radiators are oversized, the space is overheated and creates discomfort in the room [37]. This is usually controlled by the reduction of the mass flow with the use of Thermostatic Radiator Valves (TRV) on each radiator or an action by the occupant who adjusts a valve or opens a window [38]. An oversized plant can result in balancing problems, and an unbalanced system can create discomfort to occupants [35].

- Efficiency of hydraulic controls

The risk of drifting temperature is limited if the system has appropriate control [35], but oversized equipment or the poor implementation of controls can lead to control problems which, in turn, result in discomfort for the occupant $[35,39,40]$. Oversized pumps and valves can limit their authority, and the flow rate's controllability might be compromised [41]. It also creates balancing problems for the morning start-up of a plant [35]. 
Overcomplex controls are often associated with over-designed systems, which leads to a reduction in the system's efficiency [8]. Finally, [42] highlighted in 2010 that efficient controls are necessary to manage the rising internal heat gains induced by global warming.

- Valve hunting, cycling and boiler corrosion

For buildings connected to $\mathrm{DH}$, oversized control valves at the heat exchanger can cause valve hunting, where valves open and close at an uncontrolled rate, reducing the authority and life of the valve [39]. Oversized systems tend to increase the cycling of boiler plants and short (duty) cycling reduces the plant's efficiency and life [35]. More generally, oversized systems operate close to their closed position most of the time and fail prematurely [35]. Failure can also occur when oversized radiators with a constant flow circuit return low-temperature water, which can corrode the boiler [35]. However, boiler corrosion is a reduced risk since the EU has introduced policies in 1994 to gradually reduce the sulphur content in fuel oils [43], and condensing boilers are designed to achieve high efficiency with low return temperatures. In other situations, some flow from the supply line can be diverted (bypassed) back into the return in order to secure appropriate temperature before entering the boiler.

- Capital investment and operating cost

Oversized equipment is costly in capital investment and operating costs [39]. If a system fails prematurely, operates with reduced efficiency or has accelerated wear due to unstable controls, this also increases maintenance costs [35]. Oversized pumps consume excess energy, and an appropriate choice of control for a pump might be inappropriate if the pump operates at a different load due to the oversizing of the system [35]. Heating systems are expected to operate at part-load for most of the year, but this is exacerbated by oversizing, leading to inefficient operation $[35,40]$. This is combined with rising internal heat gains, which is another factor increasing the part-load operation of the system [44]. It is worth noting that increased internal heat gains have an impact on the annual duration of part-load operation but does not impact the sizing of the system.

Finally, as oversized systems do not operate under optimal performance, this impacts the ability of the building to reach carbon emission reduction targets $[45,46]$, and failing to achieve the expected performance can erode the credibility of the construction sector and lead the general public to be sceptical regarding the ability to deliver high-performance buildings, for example, net-zero energy buildings [9].

\subsubsection{Origins}

Oversizing can result from the application of margins, and nine types of margins were identified by [8]. A margin can be defined as an amount allowed beyond what is needed or an allowance for contingencies [8]. Margins are used to allow for uncertainty in (i) initial design assumptions, (ii) building performance, (iii) calculation methods used, (iv) equipment performance, (v) system performance, (vi) safety margins to enable a system to perform as designed (i.e., Pre-heat factor), (vii) futureproofing, (viii) allowance for deterioration of system performance and (ix) come from habits, customs or rules of thumb.

After the initial design assumptions, each step of the design process, construction phase, commission and operation can lead to increased margins and often cumulative margins [8] and can be described as over-specification, over-design or over-engineering.

The use of margins is presented in the CIBSE guides with methods and tools to limit oversizing, however, it is common practice for engineers to rely more on empirical margins than CIBSE guide methods [47], hence "the reduction in uncertainty can only come from improved knowledge" [17]. The lack of monitored and analysed feedbacks is identified as a key problem $[8,47,48]$, and the lack of complaint from the occupant is sometimes the only feedback used to assess a successful design [8]. For the design engineer, over-sizing can present less risk than under-sizing, and there are no incentives to correctly size a system [49]. During the design stage, components are usually selected to be larger than 
required to ensure safety margins [37], and during the procurement stage, the next size up is chosen because components are available in a limited number of sizes [19,35,50-52].

Habits and reasons of comfort can also drive the choice of the heat emitter. It can be regular practice to fit a radiator below each window to avoid cold areas and down-draught; hence, the size of the radiator is chosen by adjusting its width with the dimension of the window. This can lead to the choice of the radiator for its width and not only for its output capacity [53-55]. The oversizing of a system can also come from changes in its heat demand if the building has been through a retrofit programme $[41,44]$ or changing external conditions. The CIBSE weather files were updated in 2016 to include the latest data related to global warming and provide weather forecasts for 2050 and 2080 [56]. Global warming on systems sized with outdated weather files can influence the sizing of heating systems $[57,58]$.

\subsubsection{Magnitude}

There are numerous statements related to oversizing of heating systems such as "substantial evidence of over-design and consequent over-sizing" [8], "oversizing is common in energy infrastructure" [34] or "design stakeholders often know that their system is overdesigned, but not by how much" [45]. Furthermore, research related to oversized HVAC systems rarely focus on excess space-heating capacities but excess cooling capacities $[59,60]$. However, under-sizing is also mentioned in the literature by [61] where "under-sizing is a well-known problem in the UK". Finally, [8] highlights that oversizing is a "largely hidden topic" but detailed values are rarely available [47].

A report from Crozier in 2000 [35] shows that oversizing by 50 to $100 \%$ is common in heating systems and can reach $400 \%$. This report was used in different guidebooks as an example of the general oversizing of non-domestic buildings in the UK based on a sample of 25 buildings $[19,40]$. More recently, a report published by the Department for Business, Energy and Industrial Strategy (BEIS) estimates that $23 \%$ of systems are undersized, and a typical oversizing margin is 20 to $40 \%$ [62]. In Sweden, the degree of oversizing is typically at least $10 \%$ and very often $100 \%$ or even more [38]. In Denmark, in a piece of research looking at the oversizing of individual radiator capacities, [36] showed that some radiators were undersized, but $80 \%$ of radiators were oversized, and the degree of oversizing can extend to $350 \%$. This was compared to their current design load and homes built from the 1990s having significantly oversized systems [36,62]. In Norway, the oversizing of heating systems is estimated to be around 20 to $25 \%$ [63]. Other researchers have carried out the theoretical exercise of adding current practice margins [8,64], which can result in cumulative margins of $184 \%$ [8] and 313\% [64]. These can come from additional margins for initial data and data assumption (+20\%), engineering calculations $(+25 \%)$, installer's uplift ("Next size up"; $+15 \%)$, building construction and integrity $(+10 \%)$, system and equipment performance $(20 \%)$, safety and commissioning margins $(+25 \%)$ and maintenance and related margins $(+10 \%)$ [64]. The CIBSE undertook the same exercise in addition to heat losses $(+10 \%)$, reduction in emitter's output $(+10 \%)$, pipe losses $(+10 \%)$, pre-heat margin $(+20 \%)$ and next size up [8]. In the same report, margins occurring at each step of the design and construction process have been evaluated. It shows that the largest magnitude for overdesign relies on the choice of the pre-heat factor for the boiler (e.g., up to 200\%) and highlights that the applied margin values to heat emitters are limited to $10 \%$.

Global warming also plays its role, as a change in the external design temperature can affect the oversizing of the system by $5 \%$ per degree Celsius [8]. The consequence of oversized heating systems led to $1.8 \mathrm{GW}$ of unnecessary installed capacity of boilers in the UK in 1998 alone [8]. A boiler oversized by 150\% can lead to an increase in energy use of $15 \%$, and it is estimated that this oversizing is typically responsible for approximately $10-15 \%$ of HVAC-related energy consumption. An efficient boiler controller can save 35\% on fuel cost for a 20-year-old boiler oversized by a factor of 2.5 [35]. It may be noted that no specific trend can be identified related to age, building type or use [35]. 


\subsubsection{Benefits}

Some benefits of oversized systems are identified. The oversizing of boilers, valves and pumps provides excess capacity for future heating system expansion [45]. The oversizing of heat emitters does not enable future development but presents other benefits. The key benefit is the ability to reduce operating temperatures of the heating system within the building [39], which is further developed in Section 3.3.1. It also provides cooling, or low return temperature, to the heating circuit, which increases the efficiency and capacity of $\mathrm{DH}$. This can also increase the quantity of heat extracted from energy sources, such as condensing gas boilers, solar panels [65], geothermal heat pumps, industrial waste heat and Combined Heat and Power (CHP) [66].

Oversized emitters can also enable TRVs to operate more efficiently. This can be obtained by reducing the flow, allowing the TRV to operate with higher authority and approximatively the same differential pressure [37]. It is not economically viable to install oversized radiators to achieve low flow rate systems, but existing oversized systems especially with high flow and small temperature differential can provide these benefits [37]. Another positive point of an oversized system is the ability to compensate for the performance gap of buildings [8]. This is particularly true in the UK for post-1990 buildings with mechanical ventilation performing poorly, especially in windy conditions [67].

\subsubsection{Oversizing and Performance Gap}

The full extent of the oversizing is often hidden by higher than recommended energy use from poorly performing buildings, also known as the performance gap. Among other reasons, this performance gap can be due to high air leakage rates, sometimes resulting in up to five times the expected rate [8]. In an international survey, the average performance gap was $32 \%$, with higher values for the UK. The average performance gap in the UK was $62 \%$, with $31 \%$ in offices, $75 \%$ in schools and $82 \%$ in universities [68]. An EU benchmark of building performance also shows that UK buildings are among the worst-performing [69]. This underperformance of UK buildings is also mentioned in the guidebook [19] as "it is common knowledge that UK buildings are more air leaky than US and Scandinavian counterparts".

As for the level of oversizing, no correlation can be established between the magnitude of the performance gap and classic building parameters. Oversizing and poor system performance are still significant concerns in building services design practices $[70,71]$.

\subsubsection{Methods to Evaluate Oversizing}

According to [8], "there is no effective method to easily evaluate system's performance in use to identify oversizing", and "deficiencies are usually only obvious when systems underperform". The limited access to energy consumption can drive performance assessment to rely on estimations [72]. Without access to energy use data, the evaluation of oversizing can also be carried out with a site survey. The capacity of the radiators are estimated based on their type, size and dimensions, and the heat load of the building is estimated by comparison with typical published values [36] or with RdSAP (Reduced Data Standard Assessment Procedure) assessments specifically for domestic buildings [62,73]. It is worth noting that it is not recommended to use the rating plate of the boiler or heat exchanger for the evaluation of the capacity of the heat emitters as they could differ significantly. For example, redundancy decisions might affect the installed capacity in the plant room in non-domestic buildings [39], and the sizing of domestic gas boilers is often based on the DHW capacity [74].

However, with access to detailed data, for instance, flow and return temperatures in the heating circuits, external temperature and energy consumptions, it is possible to estimate the oversizing of the $\mathrm{SH}$ system in a specific building. This has been detailed in several studies $[35,38,75,76]$, for instance. All those works focus on space heating provided 
by wall-mounted radiators, but the principle can be applied to other types of heat emitters. The heat output of radiators is defined in EN $442[77,78]$ as per Equation (2):

$$
\dot{\mathrm{Q}}_{\mathrm{rad}}=\dot{\mathrm{Q}}_{\mathrm{rad}_{\mathrm{o}}}\left(\frac{\Delta \mathrm{T}}{\Delta \mathrm{T}_{0}}\right)^{\mathrm{n}}
$$

where $\dot{\mathrm{Q}}_{\mathrm{rad}}$ is the measured heat power in the radiators $(\mathrm{W}), \Delta \mathrm{T}$ is the Arithmetic Mean Temperature Difference (AMTD) between the supply and return temperature in the radiator $\left(T_{S}-T_{r}\right)$ and the temperature in the room $\left(T_{i}\right)$, as per Equation (3):

$$
\Delta \mathrm{T}=\left(\frac{\mathrm{T}_{\mathrm{s}}+\mathrm{T}_{\mathrm{r}}}{2}\right)-\mathrm{T}_{\mathrm{i}}
$$

$\Delta \mathrm{T}$ is also called excess temperature. The radiator exponent $n$ is usually set at 1.3 for standard radiators [79]. $\Delta \mathrm{T}_{0}$ and $\dot{\mathrm{Q}}_{\mathrm{rad}_{\mathrm{o}}}$ are relative to the design condition's values. This approach is accurate if applied to radiators with small temperature differences between flow and return or high flow rate. If the flow rate is decreased, the return temperature drops, and the mean surface temperature of the radiator is better approximated by the Logarithmic Mean Temperature Difference (LMTD), as described by McIntyre [80]. The LMTD is calculated as per Equation (4):

$$
\text { LMTD }=\left(\frac{T_{\mathrm{s}}-\mathrm{T}_{\mathrm{r}}}{\ln \left(\frac{\mathrm{T}_{\mathrm{s}}-\mathrm{T}_{\mathrm{r}}}{\mathrm{T}_{\mathrm{s}}-\mathrm{T}_{\mathrm{i}}}\right)}\right)^{\mathrm{n}}
$$

With the use of LMTD instead of AMTD, Equation (2) becomes:

$$
\dot{\mathrm{Q}}_{\mathrm{rad}}=\dot{\mathrm{Q}}_{\mathrm{rad}_{\mathrm{o}}}\left(\frac{\mathrm{LMTD}}{\mathrm{LMTD}_{\mathrm{o}}}\right)^{\mathrm{n}}
$$

British Standards are based on the AMTD [77,78], while Danish Standards are based on LMTD [81]. Equation (5) enables an evaluation of the oversizing of a space heating system at design conditions. This provides guidance on the new design temperatures that radiators could be operated at. For example, if a heating system is designed for $80 / 60{ }^{\circ} \mathrm{C}$ and the radiators are oversized by $100 \%$, the actual system design temperature is estimated to be $60 / 40{ }^{\circ} \mathrm{C}$ [41]. However, as heating systems operate most of the year at part-load, it is possible to optimise flow and/or return temperatures for every external temperature. Access to data can also provide additional information about true peak load, internal heat gains and how the system is operated.

It is worth noting that the type of radiator connection has an impact on its output capacity. A radiator can be connected with flow at the top and return at the bottom, on the same end, Top-Bottom-Same-End (TBSE) or Top Bottom Opposite End (TBOE). It can also be connected with Bottom flow Bottom return Opposite End (BBOE). The method for radiator testing, and to establish nominal capacity, varied from TBOE to TBSE, but both provided similar results $[77,82-84]$. The performance of BBOE reduces the heat output of the radiator by $4.7 \%$ to $15 \%$ compared to the TBOE connection $[80,84,85]$. This type of connection has been deemed "not advised unless absolutely necessary" by the latest Heat Network Code of Practice [84], yet, BBOE is the most common arrangement in domestic and non-domestic space heating systems in the UK $[83,86,87]$. This should be taken into account when evaluating the level of oversizing in the system.

Finally, in the UK, access to data is improving, as new energy meters installed in large non-domestic buildings must record consumption every half-hour since April 2014. The roll-out of half-hourly metering on all large energy consuming sites was completed in April 2017 [88]. The flow and return temperature can usually be provided by a Building Energy Management System (BEMS). 


\section{Space Heating and Low-Temperature Heat}

The concept of low-temperature heat comes mainly from the DH industry, where it emerged between 2010 and 2017 [89]. DH technologies have evolved, and each technology generation has seen, among other considerations, a constant reduction in the temperature distribution [7]. Each generation can be classified by flow temperature [90]. The first generation (1880s-1930s) were steam-based, with network flow temperatures above $120^{\circ} \mathrm{C}$. The second-generation (1930s-1970s) were hot water-based, with network flow temperatures above $100^{\circ} \mathrm{C}$. The third generation, introduced after the first oil crisis (1970-present) has a network flow temperature between $80^{\circ} \mathrm{C}$ and $100{ }^{\circ} \mathrm{C}$. All three initial generations were designed and based on fossil fuels to supply heat into buildings with high heat demand. This is still largely true worldwide, where fossil fuels supplied $90 \%$ of the heat in heat networks in 2014 [91]. Heat networks in Europe have started moving away from fossil fuels, where their share has reduced to 70\% [91]. The more recently defined 4GDH (2020-2050), also called low-temperature heat network, has a flow and return temperature of $55 / 25^{\circ} \mathrm{C}$ as per the definition given in 2014 [7].

Further reduction of the temperature with flow temperature close to the ground's temperature, called ultra-low-temperature, ambient loop or fifth generation systems is not suitable for direct $\mathrm{SH}$ purpose [92].

\subsection{Review of Temperature Levels in the UK}

\subsubsection{Definitions of Low-Temperature Heat}

In the UK, where DH schemes are not common, other definitions of low temperature are used. For the Standard Assessment Procedure (SAP) of residential buildings, the definition of low temperature has changed with the succeeding versions of SAP. In 2009, there was no specific definition of a low-temperature system [93]. In the 2012 version, a low-temperature heating system was defined as "one in which the hot water leaving the heat generator is always at a temperature not exceeding $45^{\circ} \mathrm{C}$ or $35^{\circ} \mathrm{C}$, even on the design day". In that case, emitters had to be sized accordingly to deliver equivalent heat as a "normal system (over $55^{\circ} \mathrm{C}$ )" [94]. The latest version of SAP, published in 2018 but not applicable to-date, defines a low-temperature heating system as "one in which the hot (flow) water leaving the heat generator never exceeds a temperature limit, even on the 'design day'". This is compared to "standard design practice for condensing boilers, where this water may reach $80^{\circ} \mathrm{C}$ or $70^{\circ} \mathrm{C}$, with a return of $60^{\circ} \mathrm{C}^{\prime \prime}$ [95]. Therefore, the notion of low temperature is not clearly defined.

In the latest edition of the CIBSE Guide A (2019), hydronic systems are classified by temperature level. Temperature below $90^{\circ} \mathrm{C}$, from $90^{\circ} \mathrm{C}$ to $120^{\circ} \mathrm{C}$, and above $120{ }^{\circ} \mathrm{C}$ are low, medium, and high temperature categories, with operating pressures of $1,3,5$ bars respectively [51].

With regard to the upcoming move away from natural gas as a source of heat and a switch towards heat pumps and district heating [6], these definitions are outdated as they represent a major constraint on DH [96]. The UK Government launched a consultation in January 2021 to implement a cap of $55^{\circ} \mathrm{C}$ of the flow temperature. This would apply to new buildings, or during the deep retrofit of an existing building, to ensure that buildings are ready for low-carbon heat [97]. The importance of providing a low return temperature, a key parameter for $\mathrm{DH}$, is not mentioned in this consultation paper. This approach, focussed on low flow temperature but without mention of the necessity to achieve low return, is also seen in a report published by the UK Government in February 2021 [62]. Further communication between the DH industry and the government is necessary to set up policies that reflect the specific requirement of $\mathrm{DH}$, and especially $4 \mathrm{GDH}$, to ensure an efficient roll-out of the technology.

However, when buildings are connected to a DH, the Heat Network Code of Practice recommends a maximum return temperature of $40^{\circ} \mathrm{C}$ for new dwellings for the radiators, fan-coil units, and Air Handling Unit (AHU) [84,98]. It also provides guidelines for a minimum temperature difference between flow and return of $30^{\circ} \mathrm{C}$ for new buildings, and 
$25{ }^{\circ} \mathrm{C}$ for existing buildings. As $\mathrm{DH}$ in the UK supplies only $2 \%$ of the current heat demand (2019), this affects only a limited number of buildings. This Code of Practice could, for example, be more widely applied to any buildings, or at least those situated in areas where $\mathrm{DH}$ is deemed feasible.

\subsubsection{Range of Design and Operating Temperatures}

There is little evidence of the current operating temperatures in the literature for the UK. This paragraph describes the various design temperatures used across the country, an evaluation of the temperatures that could achieve a well-controlled and operated system and a review of the common failings of such systems.

\section{- Design Temperatures}

Historically, heating systems in the UK have been designed to operate at $82 / 71{ }^{\circ} \mathrm{C}$ [12]. The current practice is to use both $82 / 71^{\circ} \mathrm{C}$ and $80 / 60{ }^{\circ} \mathrm{C}$ [51]. The benefits of maintaining high flow temperature and limited temperature difference are to avoid boiling, provide rapid pre-heat capacity, maintain a high return temperature in order to keep radiator size small and to prevent excessive thermal stress and prevent condensation (i.e., above $\left.60^{\circ} \mathrm{C}\right)[19,99]$. Older boilers, once exposed to corrosion problems, might have been replaced with a more modern boiler or heat pump, but the heating system to which it is connected and designed to limit the return temperature could still be in place. In the professional literature, there is still mention of the importance to maintain high return temperatures, but this is now outdated. Medium and high temperatures, above $90^{\circ} \mathrm{C}$ and $120^{\circ} \mathrm{C}$, respectively, are still considered for large non-domestic buildings where high temperature and pressure are reserved for the main distribution pipes, and temperatures below $90{ }^{\circ} \mathrm{C}$ serve the final emitters $[19,51]$. The driver here is to increase the carrying capacity and reduce the pumping cost.

The design flow and return temperature are impacted by the type of boiler installed. In domestic buildings, condensing boilers are mandatory since 2005 in England and 2007 in Scotland [100]. A heating system using condensing boilers is still designed to operate at $80 / 60^{\circ} \mathrm{C}$ or $70 / 60{ }^{\circ} \mathrm{C}$ during peak demand [51,95], hence this has a limited impact on the sizing of the heating system. In non-domestic buildings, condensing boilers are not mandatory [27], and despite having an efficiency of some $10 \%$ higher than non-condensing boilers [51], a low price of energy limits the financial benefit of the investment [101]. Therefore, condensing boilers are widely deployed in domestic buildings but less-so in non-domestic buildings. Condensing boilers require return temperatures below $55^{\circ}$ for optimal efficiency. To avoid the problem of installing large heat emitters and associated costs, the latest edition of Faber and Kell (2015), a guidebook edited since 1936, suggests continuing to size radiators for higher temperatures. The high temperature would be used during pre-heat time when the heat load is at its maximum level, and the system would operate at temperatures below $55^{\circ} \mathrm{C}$ during daytime, when the building benefits from internal heat gains [19]. To supply heat to underfloor heating, the flow temperature should be derived from higher temperatures using mixing valves or secondary circuits [19]. This shows that the importance of achieving a low supply and return temperature is not paramount in current practices.

\section{- $\quad$ Temperatures in a Well-Functioning System}

A well-functioning heating system relies on efficient controls, appropriate temperature settings, and a well-balanced hydraulic system. Buildings are operated for most of the year in reduced temperature mode. This is particularly true for non-domestic buildings, as they use weather-compensation control to reduce flow temperature during mild weather, combined with TRVs to trim local temperatures [102]. Both weather-compensation and TRVs are mandatory equipment in non-domestic buildings [26,27]. In domestic buildings, weather-compensated controls were not recommended in 2008, as they were deemed not to be cost effective [103], but TRV's have become mandatory since the 1990s [104,105]. In 2017, weather-compensated controls represented only a $2 \%$ share of the domestic market [105], 
and in domestic buildings, it is common practice that the flow temperature of the heating circuit is set manually by the occupant with the adjustment of a dial on the boiler. In 2021, the Energy Saving Trust mentioned in its recommendations to owners that "the highest the temperature is set, the quicker it will heat the home. If it's not set high enough when it's very cold outside, your home may not reach the desired temperature". It also recommend not to set the temperature too high, as condensing boilers are more efficient with return temperature below $55^{\circ} \mathrm{C}$ [106]. There is no explicit mention of the benefits of lowering the temperature when the weather is mild. Boiler manufacturers recommend setting the temperature between $60{ }^{\circ} \mathrm{C}$ and $68^{\circ} \mathrm{C}$ [107-109] or do not provide guidelines [110]. Boilers are usually preset for the recommended temperatures, and this optimal temperature is sometime displayed on the boiler's control panel.

A well-balanced hydraulic heating system provides a uniform temperature drop across all radiators. This temperature drop, at nominal conditions, is expected to be $5{ }^{\circ} \mathrm{C}$, $10-12{ }^{\circ} \mathrm{C}$ or $20^{\circ} \mathrm{C}$ depending on the boiler type or the system type; typically, it is $5^{\circ} \mathrm{C}$ for systems where a pump is installed, $10-12{ }^{\circ} \mathrm{C}$ for systems with gravity flow [19] and $20{ }^{\circ} \mathrm{C}$ when there a condensing boiler is installed [111] or higher with a connection to district heating [112]. Most recommendations from radiator manufacturers are $10-12{ }^{\circ} \mathrm{C}$ [112-115]. British Standards have also recommend a nominal temperature difference of $11^{\circ} \mathrm{C}$ since 1988 [83,99]. This is applicable for systems with outputs greater than $45 \mathrm{~kW}$. The importance to achieve a low return temperature for condensing boilers is also presented, but in a way that diminishes its impact: "Condensing boilers require relatively low return temperatures (typically below $60^{\circ} \mathrm{C}$, but it depends on type)". This code of practice (BS 6880 ) is still in use currently and should be updated to emphasise the importance of the condensing mode, eventually with guidelines to achieve such a target. Finally, one radiator manufacturer states that "temperature drop will usually be something between $10{ }^{\circ} \mathrm{C}$ and $20{ }^{\circ} \mathrm{C}$ depending on your system - if in doubt go for $12^{\circ} \mathrm{C}^{\prime \prime}$ [113].

One can conclude that a well-functioning system in a non-domestic building would operate with temperatures between $80 / 70{ }^{\circ} \mathrm{C}$ in extreme weather conditions and lower in mild weather, depending on the settings of any fitted weather-compensation equipment. For domestic buildings, the operating temperature would typically be between $60 / 40{ }^{\circ} \mathrm{C}$ and $68 / 48{ }^{\circ} \mathrm{C}$ if the occupant does not modify the default settings on the boiler and if the heating system is balanced to achieve a $20^{\circ} \mathrm{C}$ drop across the radiators.

- Common Faults and Malfunction

Faults and malfunctions have been reported in the literature and affect temperature setting, hydraulic balance and the appropriate use of other thermal and hydraulic controls.

The temperature setting of the flow temperature is often a first cause of malfunction. A survey carried out by the Heat Pump Association [116] on 182 heating installers showed that $70 \%$ of boilers were set to temperatures above $66^{\circ} \mathrm{C}$, and only $10 \%$ were set to perform at the recommended $55^{\circ} \mathrm{C}$ or lower. This is not a new situation, as, in 2016, BEIS published a consultation document where it was mentioned that "We are aware that return temperatures are often set much higher than $55^{\circ} \mathrm{C}$, and many installers feel that setting temperatures too low will result in dissatisfied customers" [117]. For non-domestic systems, the setting of the weather-compensated control curve (where fitted) is another cause of malfunction. In a survey undertaken in 2004, it was found that the compensation curves were all set inappropriately [101]. Another cause of malfunction results from the hydraulic balancing of the heating system. A study across the EU has shown that hydraulic balancing is not common either when systems are installed or when they are maintained, and only $10 \%$ of buildings had heating systems correctly balanced [118]. If the heating installer has good knowledge of low-carbon technology, the systems are usually better balanced [62]. This is also a recognised problem by the UK Government, which mentioned in 2016 that "At present, Building Regulations do not explicitly define hydraulic balancing or require central heating systems to be hydraulically balanced when replaced and Commissioned" [117]. Finally, TRVs are not installed in every building, but the published figures are inconsistent. A report published in 2021 by BEIS estimates that TRV's are used in 37\% of Scottish 
dwellings and 17\% in England [62], while a report from DECC mentioned that, in 2008, $55 \%$ of UK dwellings were equipped with TRVs [119]. At an EU level, it is estimated that less than $50 \%$ of systems have TRVs installed [118]. Finally, faults and malfunctions often go unnoticed unless seriously affecting the comfort of the occupant [62]. For instance, a radiator staying cold due to poor balancing might be noticed, but a condensing boiler operating in non-condensing mode is likely to go unnoticed.

\subsection{Design and Operating Temperature in other Countries}

With design flow/return temperatures of $82 / 71^{\circ} \mathrm{C}$, the UK has the smallest temperature difference $\left(11^{\circ} \mathrm{C}\right)$ compared to other countries. In a survey carried out by [39], it is shown that the temperature difference in Poland is $14{ }^{\circ} \mathrm{C}\left(85 / 71{ }^{\circ} \mathrm{C}\right), 20^{\circ} \mathrm{C}$ in Korea $\left(70 / 50{ }^{\circ} \mathrm{C}\right)$, Romania and Russia $\left(95 / 75^{\circ} \mathrm{C}\right)$ and Germany $\left(80 / 60^{\circ} \mathrm{C}\right)$ and $30^{\circ} \mathrm{C}$ in Denmark and Finland $\left(70 / 40^{\circ} \mathrm{C}\right)$. It is worth noting that these values originate from 2002 and are useful to understand design practice at this time but might be outdated in respect to current practice.

DH supplies to almost $50 \%$ of the heat demand for residential and non-domestic sectors in Denmark and Sweden [120]. In those countries, the market is mature for 3GDH, and many experiments have been undertaken to vary operating temperatures [121]. In Sweden, space heating systems were historically designed for a typical $90 / 70{ }^{\circ} \mathrm{C}$ or $80 / 60^{\circ} \mathrm{C}$ until the 1980s. In 1988, the development of DH and the desire to promote solar-heated buildings pushed the government to limit the design flow temperature to $55-60^{\circ} \mathrm{C}$ for new buildings. Heating systems are currently designed for $60 / 40^{\circ} \mathrm{C}, 60 / 45^{\circ} \mathrm{C}$ or $55 / 45^{\circ} \mathrm{C}$ [122-124]. Within the building, a hydraulic interface heat exchanger is designed to provide $60 / 40^{\circ} \mathrm{C}$, too [125]. In Denmark, individual heating systems in houses were typically designed for $90 / 70{ }^{\circ} \mathrm{C}$ before $1990,70 / 40{ }^{\circ} \mathrm{C}$ in the 1990 s and are currently at $60 / 40{ }^{\circ} \mathrm{C}$ [44].

In 2017, a survey of radiators serviced by DH in Sweden showed that the average flow and return temperature were $64 / 42{ }^{\circ} \mathrm{C}$ in extreme weather condition and that the flow temperature was always below $55^{\circ} \mathrm{C}$ if the external temperature was $5{ }^{\circ} \mathrm{C}$ or more [124]. Another study reported that multi-family buildings could be supplied by $50 / 30{ }^{\circ} \mathrm{C}$ or $45 / 35^{\circ} \mathrm{C}$, even with outdoor temperatures around $0{ }^{\circ} \mathrm{C}$ [52]. It was concluded in [121] that a well-functioning space heating system can be supplied with temperatures of $40-70{ }^{\circ} \mathrm{C}$ and provide return temperatures as low as 25 to $35^{\circ} \mathrm{C}$. A 'well-functioning' system is one where the heat exchanger is appropriately designed and sized and hydraulically balanced.

It is common practice to use weather-compensation controls both at the DH level and the substation [126]. The ability to reduce the operating temperature in well-functioning space heating systems enables DH operator to reduce temperatures in the DH. This is supported by various case studies. For example, in Denmark, a DH company supplying 5000 customers, domestic and non-domestic, at a temperature of $81 / 48^{\circ} \mathrm{C}$ were able to drop the network temperatures down to an annual average of $65 / 40^{\circ} \mathrm{C}$ without building retrofit. The only actions undertaken were a service check and advice provided to customers who were experiencing a malfunction of their system and the introduction of financial incentives for reduced return temperatures to motivate the customer to improve their installation [127].

In Denmark, $\mathrm{DH}$ operates with varying temperature across the year with an average of $78^{\circ} \mathrm{C}$ (ranging from $65^{\circ} \mathrm{C}$ to $80^{\circ} \mathrm{C}$ ) for the flow and an average of $43^{\circ} \mathrm{C}$ (ranging from $32{ }^{\circ} \mathrm{C}$ to $42{ }^{\circ} \mathrm{C}$ ) for the return. In Sweden, the average supply temperature is $86^{\circ} \mathrm{C}$, and the average return is $47^{\circ} \mathrm{C}$ [128-130].

In addition, it is worth noting that radiators in Danish and Swedish systems are connected with TBOE, which provides them an optimal capacity compared to the BBOE connection commonly used in the UK [84]. Recommendations to connect radiators TBOE in the UK should be implemented, as these would generate higher efficiency for limited constraint on the heating industry/installer. 


\subsection{Benefits and Challenges of Low-Temperature Heat}

\subsubsection{Benefits}

The need to progress towards the 4GDH and low-temperature networks has two main reasons. The first comes from countries where DH is deployed. With the development of tighter energy performance standards for new buildings and vast programmes of energy renovations [131], the heat demand from customers is reduced. DH companies are therefore facing reduced heat demand, while grid losses remain constant. To keep heat networks cost-effective, they need to reduce the operative temperature to reduce grid losses $[50,89,91,92,132-139]$. The second reason is the integration of low-grade heat and the achievement of a $100 \%$ renewable energy system $[7,89,140]$. Low-temperature District Heating (LTDH) can facilitate the integration of variable electricity production, for example, wind and solar energy sources [141]. It can be noted that this is of particular interest in countries with a high share of electricity from wind sources, for instance, the UK.

\subsubsection{Challenges}

The radiator is the main type of heat emitter in the UK, with up to $80 \%$ in nondomestic buildings [101]. Other typical heat emitters are underfloor and AHU. Underfloor heating generally requires temperatures below $40{ }^{\circ} \mathrm{C}$ and is therefore usable for lowtemperature heat $[127,142]$. Mechanical ventilation heat exchangers for AHU's would require modifications of the coils to accommodate lower temperature and is not deemed to represent a significant challenge to adapt to LTDH [143]. Discussion with experts in the industry highlight that AHU retrofit could still pose problems with the physical integration of larger coil banks. However, the most pressing challenge is the capacity of existing radiators with reduced operating temperatures [143].

A reduction in the operating temperature directly impacts the efficiency of the radiator. The rated thermal output of heat emitters has to be declared at a temperature difference of $30{ }^{\circ} \mathrm{C}$ and $50{ }^{\circ} \mathrm{C}$ [78]. When the operating temperature is reduced to below design conditions, the heat output of the radiator drops below its rated output. This is acceptable in mild conditions but impacts the radiator's output capacity in colder weather or during preheat time if the system operates on intermittent mode. In the transition towards $4 \mathrm{GDH}$, this reduced capacity is exacerbated if the system is designed for high operating temperature, as in the UK, compared to those designed for lower operating temperatures, such as $3 \mathrm{GDH}$. Further details about a radiator's heating capacity can be found in $[79,80,112,144,145]$.

Another challenge for developing low-temperature district heating is the disconnection between a building renovation strategy and the rollout of low-temperature district heating [146]. Local authorities, supported by national governments, have a key role in the implementation of coordinated strategies [146]. To establish these strategies, improved access to data related to the availability of local heat sources and that of the building's heat demand are necessary [146].

A lack of data related to a building performance also has a major impact on a system efficiency once the system is up and running. Commonly, DH systems fail to achieve the expected performance due to inappropriate operation in the buildings that they supply [32]. This is because the efficiency of the DH is driven by its operating temperatures, which is in turn driven by the building's heating system, over which heat network companies rarely have any control. Thus, very little is known about a customer's installation, yet it is a key driver for an efficient system $[147,148]$. Furthermore, while systems are designed to achieve a low return temperature, a succession of failings such as wrong temperature setting, faulty components, hydronic imbalance, or bypasses, prevent them from reaching target temperatures. As those faults have a high impact on the ability to provide a low return temperature, malfunction detection for a heating system is a currently active field of research $[130,147,149]$. The control of radiators employing low-temperature supply is similar to traditional temperature supply systems; the main difference being the risk of higher mass flow and high return temperature [150]. Therefore, the quality of a radiator's control has an increasing role when the operating temperature is reduced. In the UK, 
the poor efficiency of TRVs may lead to problems in delivering the appropriate control of flow and difficulties in ensuring a low return temperature [101]. It has been demonstrated that a relatively small number of open or faulty TRVs can significantly increase the return temperature. This would advocate for an alternative approach to the standard low-flow/low-return approach. This alternative approach can be low-supply/high-flow, which relies on a minimum supply temperature weather-compensated curve and high flow rate. A study shows that this method is a low-cost solution to achieve low return temperatures when the space heating system has faulty TRVs [151]. Another argument to support this approach is that a lower heat distribution loss constitutes a minor component of the total cost reductions, while the highest cost benefits are related to lower energy supply costs from geothermal heat, surplus industrial heat and heat pumps. [152]. The ability of a system to use reduced flow temperature has an impact on the efficiency of the heat source and, by consequence, on energy decarbonisation targets. This is why a low flow temperature is paramount to maintaining a high level of efficiency of heat pumps. Failure to achieve the expected coefficient of performance of new heat pumps is identified as a risk to reach national decarbonisation targets [153]. This would advocate for the necessity to focus on optimal supply temperature rather than optimal return temperature.

In order to reduce faults and errors, the end-user's behaviour is a key parameter. This highlights the necessity to involve such in the management of heating systems. For this purpose, the heat supplier will often take over the management of the heating system or set up an appropriate tariff structure to financially incentivise the client to deliver a low return and is common in Scandinavian countries [122]. For example, Danish DH companies bill their client on energy use and average return temperature [128]. The strategy is to award consumers for low return temperatures and an additional charge if the return temperature exceeds an established limit [154]. Such a tariff structure is uncommon in the UK and, should it be implemented, non-domestic clients will be targeted first [155]. Occupants of domestic buildings might have limited understanding of their heating and hot water systems $[155,156]$. Therefore, customer knowledge is needed [155].

Brand and Svendsen [50] raised the question of the difference between air and operative temperature at reduced system temperatures and the true level of temperature set by occupant comfort needs. The requirements for thermal comfort are based on operative temperature, typically $20^{\circ} \mathrm{C}$ [157], when most heating controls are based on dry air temperature [158]. In most cases, measuring the average room air temperature is sufficient to estimate the operative temperature $[157,159]$, and this is especially true for well-insulated buildings [17]. Brand and Svendsen (2013) concluded that, for poorly performing Danish buildings, the magnitude of the increased capacity needed to provide comfort to the occupant is limited, and the use of air or operative temperature does not make a significant difference. More generally, occupants tend to set the operative temperature at a higher setting, for example, $22{ }^{\circ} \mathrm{C}$ in Denmark [160], which has an impact on the heating's output capacity. As the UK has a building stock with below-average performance, further study is necessary to confirm if air temperature can be used as a good proxy for operative temperature or if occupants are setting their comfort temperature at a higher level than design specifications.

According to a survey with experts of the DH industry, the main barrier for the implementation of the LTDH concept is the need to boost the flow temperature for both thermal comfort and the pasteurisation of DHW [89]. For these experts, other barriers are the high capital investment, the need to develop a specific business model and the retrofit of existing substations and radiators. The reduction in the widely adopted $80^{\circ} \mathrm{C}$ flow temperature faces several limitations and thresholds. The first one is $65^{\circ} \mathrm{C}$; at temperatures below $65^{\circ} \mathrm{C}$, there is a risk of Legionella Pneumophila forming in the DHW system. To avoid this risk, water storage tanks must be maintained above $60{ }^{\circ} \mathrm{C}$ in the UK [161], as well as in other EU countries [137]. The second threshold is $50{ }^{\circ} \mathrm{C}$ as it is the minimum temperature required at the tap for DHW [161]. In the UK, the new Code of Practice for heat networks [84] requires $50^{\circ} \mathrm{C}$ at an instantaneous hot water heating system outlet if the 
volume of water is below 15 litres, and the hot water must reach the tap at $45^{\circ} \mathrm{C}$ within $45 \mathrm{~s}$. The last threshold is around $30^{\circ} \mathrm{C}$, as this approaches the required minimum temperature deemed suitable for $\mathrm{SH}$ comfort requirements in northern climates [44].

\subsection{Low-Temperature in Low Energy Buildings}

Low-temperature heat is deemed suitable for low-energy buildings, but the definition of low-energy buildings is unclear. For [162], a low-energy new building is a building that is "designed to achieve or to come close to the Passivhaus standard". The Passivhaus standard requires that the heat demand for $\mathrm{SH}$ is below $15 \mathrm{kWh} /\left(\mathrm{m}^{2} \cdot \mathrm{yr}\right)$ for new buildings and below $25 \mathrm{kWh} /\left(\mathrm{m}^{2} \cdot \mathrm{yr}\right)$ for renovated buildings. In Norway, low energy buildings are those built with TEK10 or Passivhaus building standards, and these buildings represent 3\% and $0.1 \%$ of the domestic stock [163]. In Sweden, a building is considered low energy if its Energy Use Intensity (EUI) is below $100 \mathrm{kWh} / \mathrm{m}^{2}$, and this represents $10 \%$ of domestic buildings and $30 \%$ of non-domestic buildings [122]. In the definition of 4GDH, [7] describes it as appropriate for new buildings using less than $25 \mathrm{kWh} /\left(\mathrm{m}^{2} \cdot \mathrm{yr}\right)$ or existing buildings using 50 to $150 \mathrm{kWh} /\left(\mathrm{m}^{2} \cdot \mathrm{yr}\right)$.

Low-temperature district heating is suitable for newly constructed buildings, as they are assumed low energy buildings, combined with low-temperature heating systems incorporating underfloor heating or low-temperature radiators [164]. Identifying a lowenergy building by age group is not possible as the most recent buildings are not necessarily the most efficient when the oldest is not the less performing [122]. A breakdown of EUI per archetype, use, size and ownership does not clearly explain the extensive variation in heat use. This seems to be the case in Sweden [122], Denmark [128], the UK [46,67,165] and in Switzerland, where "Buildings constructed before 1921 performed better than the stock average and buildings built between 1947 and 1979, which constitute the largest share of stock, performed worse" [166].

\subsection{Low-Temperature in Existing Buildings}

One of the major challenges for the development of 4GDH is to provide low-temperature heat to existing buildings designed for higher operating temperatures [50,91]. By 2050, 80\% of the existing buildings will still be in use as the regeneration rate of the building stock in European countries is 1.2 to $1.5 \%$ [167]. When low-temperature heat is considered in an existing building, one approach is to increase the size of radiators. BEIS indicates that it was common practice for heat installer to multiply the capacity of a radiator by 2.4 when a low temperature system is retrofitted [62]. Another approach is to use underfloor heating. However, that may not be sufficient for poorly performing buildings, may not guarantee a low return temperature and can be expensive or technically impossible [168]. A last approach is to upgrade insulation and single-glazed windows and fit new radiators [90].

Most of the published journal articles and technical reports apply to countries where $3 \mathrm{GDH}$ is a mature market, for example, Denmark and Sweden, and studies applied to UK buildings are more limited. The literature explores what level of retrofit is necessary to enable the use of low-temperature heat and classifies retrofit levels into four categories: (i) no retrofit, (ii) change of window, (iii) change of emitters system and (iv) retrofit of the envelope. Only a few documents focused on the degree of oversizing which is necessary to use low-temperature heat. The following four paragraphs review the impact of the various levels of retrofit applied to buildings and is followed by the impact of oversizing of systems.

\section{- No retrofit}

A study applied to a building built under Finnish building standards [54] finds that a heating system sized for operating temperatures of $70 / 40^{\circ} \mathrm{C}$ can reduce flow and return temperatures down to $45 / 35^{\circ} \mathrm{C}$ for SH. In this work, internal heat gains were not accounted for. This shows that recent buildings can use low-temperature heat without retrofit, but two elements limit this conclusion. This work was based on theoretical values and therefore does not include the eventual performance gap. The second reason is that 
radiators were sized to match the width of windows, eventually leading to an unknown degree of oversizing.

Other studies, applied to older buildings in Denmark, show that the use of a flow / return temperature of $55 / 25^{\circ} \mathrm{C}$ can supply $92 \%$ of the heat demand [50] or most of the year with $55 / 35^{\circ} \mathrm{C}$ [52]. In Norway, achieving $60 / 40{ }^{\circ} \mathrm{C}$ is possible for all buildings built pre-1956 or post-1971. For buildings constructed between 1956 and 1971, 97\% of the heat demand can be met. In this work, the heating system is sized to provide an internal comfort temperature of $22{ }^{\circ} \mathrm{C}$, but $19{ }^{\circ} \mathrm{C}$ is deemed acceptable during the coldest days [63]. If the occupant increases the internal temperature to $22^{\circ} \mathrm{C}$, only $78 \%$ of the heat demand can be met [50]. These authors concluded that existing buildings could connect to low-temperature heat if the flow temperature of the $\mathrm{DH}$ is raised during the coldest days. This is in line with current practice in the DH industry, which modulates the temperature flow with the external climatic condition; hence, a slight increase during the coldest days of the year is deemed acceptable [44]. Another way to increase the heating capacity during the coldest days is to temporarily increase the mass flow rate of the working fluid in the heating system within the building. One drawback of this method is that this causes an increase in the return temperature and the limitation is the maximum design flow allowed within the radiators and piping system [50]. Achieving reduced operating temperatures for most of the year is enabled by the fact that space heating systems operate most of the year in part-load, where the heat emitters are large enough to minimize the supply temperature. In this way, the level of building renovation in Scandinavian countries would simply allow a further reduction in the supply temperature, however, it is not a prerequisite.

In the UK, a study published in 2021 applied to domestic buildings showed that buildings were less able to use reduced flow temperatures. It concludes that with a flow temperature of $85^{\circ} \mathrm{C}, 89 \%$ of buildings could meet the heat demand at external design conditions. This meant that $11 \%$ of the building stock had undersized radiators for design conditions. At a flow temperature of, say, $65{ }^{\circ} \mathrm{C}, 46 \%$ of the buildings would be able to meet the peak demand. If the flow temperature was dropped to $55^{\circ} \mathrm{C}, 10 \%$ of existing buildings would already be able to provide appropriate comfort [62]. The study concludes that the 2.4 ratio used when radiators are retrofitted is overestimated. However, this study has some important limitations. (i) The calculation of the heat output of radiators is based on its AMTD. It has been demonstrated that this overestimates the heat output, especially with lower temperature range [80]. (ii) The study using RdSAP which demonstrates that the more recent a building is, the lower its Energy Use Intensity $\left(\mathrm{kWh} /\left(\mathrm{m}^{2} \cdot \mathrm{yr}\right)\right.$ is. This has been challenged by numerous publications based on true energy use (cf. Section 3.4). Those limitations tend to over-estimate the degree of oversizing, and therefore over-estimate the ability of the buildings to use low temperature heat.

- Windows

Over time, existing buildings have probably been through moderate retrofit, which is likely to include new windows [44]. In that scenario, a low-temperature supply of $55^{\circ} \mathrm{C}$ can meet heat demand for over $96 \%$ of the year and this has been largely documented $[50,52,163,169,170]$. Again, a limited increase in the temperature of the DH supply temperature during the coldest days enables the system to meet $100 \%$ of the demand [164].

\section{- Change of emitters}

When larger radiators are considered, the replacement can be applied to the entire system $[50,170]$ or by targeting only critical radiators such as replacing one out of five radiators was found sufficient by [75]. The same approach is used when a heat pump is retrofitted in an existing home as a third to a half of the radiators are usually replaced, some being large enough already [168]. In each scenario, it is possible to supply $100 \%$ of the heat demand with temperatures of 50 to $55 / 25^{\circ} \mathrm{C}$. The use of radiators with increased heat convection is more effective than just oversizing the radiator [171].

- Retrofit of the envelope 
Retrofit of the building envelope is another way to reduce the temperature supply and return [50], which can be as low as $35^{\circ} \mathrm{C}$ and still meet occupant comfort needs [171]. The degree of retrofit can be impacted by the efficiency of the heat emitters. If the supply temperature is reduced to $40{ }^{\circ} \mathrm{C}$ with conventional radiators, the heating system can cover a heat demand of $15 \mathrm{~W} / \mathrm{m}^{2}$. Using radiators with enhanced emissions rates enables them to cover the heat demand of a building with a heat demand of $20 \mathrm{~W} / \mathrm{m}^{2}$ [172]. Considering the capital investment of an envelope retrofit, the choice to retrofit the envelope should be linked to the economics of the associated energy saving more than the ability to use low-temperature [171].

- Oversizing of heat emitters

Østergaard and Svendsen investigated a survey study of 1645 Danish houses where the plumber-evaluated heat load of the houses was compared with typical design values and tabulated. Visible retrofit history was also included in this evaluation. The heat output of radiators was estimated based on their dimensions, and it was concluded that $80 \%$ of the radiators were over-dimensioned with an oversizing going up to $350 \%$. This should enable the operating supply temperature to drop from the classic $70^{\circ} \mathrm{C}$ in Denmark to below $60^{\circ} \mathrm{C}$ for most of the year. It is reported in the UK that heating systems are notoriously undersized and the prevalence of tenement block construction in poorly maintained conditions will not be able to use low-temperature heat [61]. The level of undersized systems is estimated at $23 \%$ of the stock in [62]. However, under-sized radiators can also cope with reduced supply temperatures, as extreme external design conditions rarely occur [36].

An evaluation of $30 \%, 50 \%$ and $100 \%$ oversizing factors has been carried out for houses in Norway [163]. They found that an oversizing of 50\% enabled a drop in supply temperature down to $55{ }^{\circ} \mathrm{C}$ for $99 \%$ of the year. Combining an oversizing factor of $30 \%$ with a retrofit of new windows enables the use of $55^{\circ} \mathrm{C}$ flow temperatures all year round. An oversizing of $100 \%$ enables a drop in the supply temperature down to $50{ }^{\circ} \mathrm{C}$. With an assumed oversizing of $20-25 \%$ in Norway [63], light renovation could enable the use of supply temperature of $55^{\circ} \mathrm{C}$ without changing the heating system.

In conclusion, buildings connected to DH need limited measures to enable the use of $4 \mathrm{GDH}$. These measures can be a temporary rise of the network supply temperature during the coldest days of a year, a retrofit of the original windows or a change of critical radiators. In those cases, the heat emitters are large enough to minimize the supply temperature. This ability to use low temperatures is described by [128] as a "nascent readiness" in Denmark for 4GDH. For buildings using gas boilers in the UK, a more limited number of dwellings are currently able to use supply temperatures of $55^{\circ} \mathrm{C}$, but further work is necessary to better understand the full impact of LTDH on UK building stock.

\section{Conclusions}

Achieving net-zero emissions from the building sector in the UK involves replacing all gas boilers with new technologies such as heat pumps or low-temperature district heating commonly called fourth generation district heating (4GDH). Both technologies are efficient at reduced temperatures, typically $55 / 25^{\circ} \mathrm{C}$, when existing buildings have been designed for $82 / 71^{\circ} \mathrm{C}$. Understanding how existing buildings can use these reduced temperatures is paramount for an efficient phase-out of gas boilers. This paper reviewed how space heating systems have been sized over time in the UK and the degree of oversizing in existing space heating systems. It also reviewed what levels of design and operating temperature are currently used in the UK and abroad. Finally, it reviewed how energy efficiency measures associated with a degree of oversizing of the heating system enable the use of low-temperature heat in existing buildings.

The investigation showed that methods to size a heating system have not changed over time, but in existing buildings, the adequacy between the size of a heating system and the heat demand is rarely optimal and systems are usually oversized. Heating systems are sized for extreme conditions that rarely occur, and therefore, systems operate most of the year under part-load. This is exacerbated if the system is oversized. Oversizing 
comes from changes in heating systems which had to adapt to modern levels of comfort, retrofit history of the building or the use of margins at various stages of the design and construction process. In the design process, the major oversizing factor comes from the pre-heat factor used for intermittent operation of the heating system. Recommendations for the pre-heat factor have fluctuated by up to $200 \%$ while a limit of $20-25 \%$ has always been deemed sufficient. The sizing of a system often relies on empirical use of margins by the design engineer, but the lack of feedback limits improvements. In addition, oversizing presents less risks than under-sizing a system. Oversizing is generally associated with reduced performance, reduced efficiency, increased capital and operating cost and can lead to reduced credibility of the building industry to deliver net-zero buildings. It should be noted that oversizing can be hidden by poorly performing buildings. Oversizing, similar to the energy performance gap, is still an issue in recent buildings, in the UK and abroad, and is not linked to building's age group, archetype or use. Oversized heating systems are a well-established fact, but their magnitude and degree are rarely investigated. However, oversized emitters can benefit from the transition towards the fourth generation district heating. They enable the use of lower temperature flow and provide better cooling of the hydronic fluid, both key drivers of efficiency in low-temperature district heating systems. In the UK, oversizing of $50 \%$ to $100 \%$ is common practice and can reach $400 \%$, but $23 \%$ of dwellings are undersized. Abroad, its magnitude is estimated to be $20-25 \%$ in Norway. In Denmark, $80 \%$ of individual radiators are oversized, some up to $350 \%$.

Research, essentially in Sweden and Denmark, shows that systems already connected to district heating can use 4GDH temperatures for most of the year. Limited retrofitting, such as new windows, change of critical radiators or an oversizing factor of 30 to $50 \%$ of the heating system, is sufficient to enable the use of low-temperature heat all year round. However, while oversizing and building retrofitting facilitate the use of reduced temperature, it is not a prerequisite, as space heating systems already operate below design conditions when weather-compensated controls are used, and this also applies to under-sized systems. Weather-compensated controls are common practice in non-domestic buildings and district heating systems but are rarer in UK dwellings. Finally, buildings in Scandinavia have a nascent readiness for low-temperature heat as they can use it for most of the year without retrofit. Limitations come from faults and malfunctions of the systems. In conclusion, the lessons from Scandinavian countries should be exported with caution into the UK.

The first identified limitation is the current level of operating temperature in the UK, which is higher than in countries where district heating is widely deployed. In the UK, the dominance of natural gas at relatively low cost has led to the development of heating systems operating at a high level to reduce the size of the radiators. Consequently, systems already connected to $3 \mathrm{GDH}$ have a smaller step to jump in order to operate under 4GDH metrics. Moreover, the importance of providing cooling to the heating circuit does not exist in the UK, despite the wide use of condensing gas boilers, which currently operate in non-condensing mode as return temperatures are generally too high. The second limitation is that buildings connected to district heating tend to operate with continuous space heating provision while this is rarely the case in the UK. The third limitation is the gap in knowledge related to the performance of heating systems in the UK. The building stock in the UK is some of the oldest in the EU and performs poorly compared to other EU countries. The fourth limitation is related to building and heating system design policies. Sweden and Denmark, for example, started the journey to develop district heating in the 1980s, whereas the UK is only just considering such measures in 2021. Current legislation and guidelines in the UK are outdated, and the actual move towards low-temperature heat does not include the specificities of district heating technologies and especially not $4 \mathrm{GDH}$. They are generally focussed on heat pump adoption and the electrification of heat. Further research is necessary to confirm if and how lessons from other countries can be applied to UK building stock. Such research should focus on the operating temperatures 
currently used across domestic and non-domestic buildings, true peak load and the degree of oversizing of space heating systems.

To prepare an efficient development of 4GDH in the UK, some recommendations for policy makers are drawn from this review and are detailed hereafter. They aim to make building stock in the UK ready for 4GDH:

(i) The current radiator connection type BBOE should not be allowed as this reduces the output capacity of radiators by 5 to $15 \%$, limiting the ability to provide a low return temperature. This would generate little constraints on current heating industry/installer practice.

(ii) The current definitions of low-temperature heat in the UK are outdated. The definition of low-temperature heat should be aligned with the standard developed around $4 \mathrm{GDH}$.

(iii) The recommendations for operating temperatures from the Heat Network Code of Practice should be applied to any buildings, or at least those situated in areas where DH is deemed feasible.

(iv) The code of Practice BS6880 should be updated to clearly highlight the importance of low return temperatures for condensing boilers.

(v) Building regulations should clearly define hydraulic balancing or require central heating systems to be hydraulically balanced when commissioned and/or replaced.

Author Contributions: Conceptualization: A.R. and B.V.; investigation: A.R.; writing-original draft preparation: A.R.; writing-review and editing: B.V. and J.C.; supervision: J.C. and B.V.; funding acquisition: A.R. All authors have read and agreed to the published version of the manuscript.

Funding: This research was funded by Edinburgh Napier University, Energy Technology Partnership (grant ref ETP162) and Vattenfall Heat UK.

Conflicts of Interest: The authors declare no conflict of interest.

\section{Nomenclature}

$\begin{array}{ll}\text { Variables } & \\ \text { OF } & \text { Oversizing Factor } \\ \text { LMTD } & \text { Logarithmic Mean Temperature Difference }\left[{ }^{\circ} \mathrm{C}\right] \\ \mathrm{T}_{\mathrm{f}} & \text { Flow temperature of radiator }\left[{ }^{\circ} \mathrm{C}\right] \\ \mathrm{T}_{\mathrm{r}} & \text { Return temperature of radiator }\left[{ }^{\circ} \mathrm{C}\right] \\ \mathrm{T}_{\mathrm{i}} & \text { Ambient temperature in the room }\left[{ }^{\circ} \mathrm{C}\right] \\ \dot{\mathrm{Q}} & \text { Heat flow }[\mathrm{W}] \\ \text { Indices } & \\ \mathrm{n} & \text { Radiator exponent, usually set to } 1.3 \\ \mathrm{O} & \text { Design condition } \\ \text { rad } & \text { Radiator }\end{array}$

\section{References}

1. United Nations Framework Convention on Climate Change (UNFCC). The Paris Agreement. 2015. Available online: https: / / unfccc.int/documents/184656 (accessed on 27 October 2021).

2. UK Government. United Kingdom of Great Britain and Northern Ireland's Nationally Determined Contribution. 2020; pp. 68-134. Available online: https:/ / www.gov.uk/government/publications/the-uks-nationally-determined-contribution-communicationto-the-unfccc (accessed on 27 October 2021).

3. Scottish Government. Climate Change (Emissions Reduction Targets) (Scotland). 2019. Available online: https://www.legislation. gov.uk/asp/2019/15/enacted (accessed on 27 October 2021).

4. BEIS UK Government. Energy Consumption in the UK (ECUK)-Excel. 2020. Available online: https://www.gov.uk/government/ statistics/energy-consumption-in-the-uk-2020 (accessed on 27 October 2021).

5. BEIS (UK Government). Digest of United Kingdom Energy Statistics (DUKES 2018). 2018. Available online: www.nationalarchives. gov.uk/doc/open-government- (accessed on 26 July 2019).

6. Committee on Climate Change. The Sixth Carbon Budget-The UK's path to Net Zero. 2020. Available online: https://www. theccc.org.uk/publication/sixth-carbon-budget/ (accessed on 27 October 2021). 
7. $\quad$ Lund, H.; Werner, S.; Wiltshire, R.; Svendsen, S.; Thorsen, J.E.; Hvelplund, F.; Mathiesen, B.V. 4th Generation District Heating (4GDH). Integrating smart thermal grids into future sustainable energy systems. Energy 2014, 68, 1-11. [CrossRef]

8. CIBSE. Engineering Design Calculations and the Use of Margins-Extracts from Research Report 4; CIBSE: London, UK, 1998 ; Volume 50.

9. De Wilde, P. The gap between predicted and measured energy performance of buildings: A framework for investigation. Autom. Constr. 2014, 41, 40-49. [CrossRef]

10. BEIS UK Government. Heat Networks Data Tables Revised. 2018. Available online: https://www.gov.uk/government/uploads/ system/uploads/attachment_data/file/712371/Heat_networks_data_tables_revised.xlsx (accessed on 27 October 2021).

11. Piddington, J.; Nicol, S.; Garrett, H.; Custard, M. The Housing Stock of The United Kingdom. 2020. Available online: https:/ files. bregroup.com/bretrust/The-Housing-Stock-of-the-United-Kingdom_Report_BRE-Trust.pdf (accessed on 27 October 2021).

12. IHVE. A Guide to Current Practice; IHVE: London, UK, 1955.

13. IHVE. Guide; IHVE: London, UK, 1965.

14. IHVE. Guide Book, A; IHVE: London, UK, 1970.

15. CIBSE. CIBSE Guide Volume A; CIBSE: London, UK, 1986.

16. CIBSE. CIBSE Guide A; CIBSE: London, UK, 2006.

17. CIBSE. CIBSE Guide A: Environmental Design; CIBSE: London, UK, 2019.

18. IHVE. Domestic Services Engineering; IHVE: London, UK, 1974.

19. Oughton, D.; Wilson, A. Faber E Kell's Heating and Air-Conditioning of Buildings, 11th ed.; Routledge: Abingdon, UK, 2015.

20. Hayward, R.H. Rules of Thumb Technical Note 5/88; BSRIA: Bracknell, UK, 1988.

21. Hawkins, G. Rules of Thumb: Guidelines for Building Services, 5th ed.; BSRIA (Building Services Research and Information Association): Bracknell, UK, 2011.

22. Mavrogianni, A.; Johnson, F.; Ucci, M.; Marmot, A.; Wardle, J.; Oreszczyn, T.; Summerfield, A. Historic variations in winter indoor domestic temperatures and potential implications for body weight gain. Indoor Built Environ. 2013, 22, 360-375. [CrossRef] [PubMed]

23. Parsloe, C.J. Over Engineering in Building Services-An International Comparison of Design and Installation Methods; BSRIA Ltd.: Bracknell, UK, 1995.

24. Day, A.; Ratcliffe, M.; Shepherd, K. Sizing central boiler plant using an economic optimisation model. In CIBSE National Conference; CIBSE: London, UK, 2001.

25. Faber, O.; Kell, J.R. Heating and Air Conditioning of Buildings, 2nd ed.; The Architectural Press: Cheam, UK, 1943.

26. Scottish Government. Non-Domestic Building Services Compliance Guide For Scotland (2015 edition), Scotland. 2015. Available online: https:/ / www.gov.scot/binaries/content/documents/govscot/publications/factsheet/2018/12/building-standardslist-of-guidance/documents /non-domestic-building-services-compliance-guide-for-scotland-2018/non-domestic-buildingservices-compliance-guide-for-scotland-2018/govscot\%3Adocument (accessed on 27 October 2021).

27. HM Government. Non-Domestic Building Services Compliance Guide_For Use in England; NBS: London, UK, 2013.

28. BSRIA. A Guide to HVAC Building Services Calculations; BSRIA: Bracknell, UK, 2007; Volume 1.

29. Day, A.R.; Ratcliffe, M.S.; Shepherd, K.J. Heating Systems, Plant and Control; Blackwell: Oxford, UK, 2003.

30. Pineau, D.; Rivière, P.; Stabat, P.; Hoang, P.; Archambault, V. Performance analysis of heating systems for low energy houses. Energy Build 2013, 65, 45-54. [CrossRef]

31. Gadd, H.; Werner, S. Heat load patterns in district heating substations. Appl. Energy 2013, 108, 176-183. [CrossRef]

32. Matrose, N.A.; Obikese, K.; Belay, Z.A.; Caleb, O.J. From time series to image analysis: A transfer learning approach for night setback identification of district heating substations. J. Build. Eng. 2021, 706, 135907. [CrossRef]

33. Hitchin, R. Price structures for electricity supply and potential consequences for building services systems. Build. Serv. Eng. Res. Technol. 2021, 42, 421-433. [CrossRef]

34. Jones, D.A.; Eckert, C.M. Design margins: Impacts on building energy performance. In Proceedings of the DESIGN 2016 14th International Design Conference, Dubrovnik, Croatia, 16 May 2016; DS 84. pp. 1295-1304.

35. Crozier, B. Enhancing the Performance of Oversized Plant; BSRIA: Bracknell, UK, 2000.

36. Østergaard, D.S.; Svendsen, S. Are typical radiators over-dimensioned? An analysis of radiator dimensions in 1645 Danish houses. Energy Build. 2018, 178, 206-215. [CrossRef]

37. Lauenburg, P. Temperature Optimization in District Heating Systems. Advanced District Heating and Cooling (DHC) Systems; Elsevier Ltd.: Amsterdam, The Netherlands, 2015; pp. 223-240. [CrossRef]

38. Ljunggren, P.; Wollerstrand, J. Optimum performance of radiator space heating systems connected to achieve lowest possible district heating return temperature. In Proceedings of the 10th International Symposium on District Heating and Cooling, Hannover, Germany, 3-5 September 2006.

39. Skagestad, B.; Mildenstein, P. Programme of Research, Development and Demonstration on District Heating and Cooling; International Energy Agency: Paris, France, 2002.

40. CIBSE. KS8: How to Design a Heating System; CIBSE Knowledge Series: London, UK, 2014.

41. Lauenburg, P.; Wollerstrand, J. Adaptive control of radiator systems for a lowest possible district heating return temperature. Energy Build. 2014, 72, 132-140. [CrossRef]

42. De Wilde, P.; Tian, W. Predicting the performance of an office under climate change: A study of metrics, sensitivity and zonal resolution. Energy Build. 2010, 42, 1674-1684. [CrossRef] 
43. European Council. Directive 93/12/EEC Relating to the Sulphur Content of Certain Liquid Fuels. 1993, pp. 81-83. Available online: https:/ / op.europa.eu/s/tAmM (accessed on 27 October 2021).

44. Skaarup, D. Heating of Existing Buildings by Low Temperature District Heating; DTU: Lyngby, Denmark, 2018.

45. Jones, D.A.; Eckert, C.M. Empowering decision makers to avoid the oversizing of building service systems. In Proceedings of the Design Society: International Conference on Engineering Design, Delft, The Netherlands, 5-8 August 2019; pp. 1135-1144.

46. Bacon, M. Occupancy analytics: A new basis for low-energy-low-carbon hospital design and operation in the UK. Archit. Eng. Des. Manag. 2014, 10, 146-163. [CrossRef]

47. Hudson, G. Technical note: The use of the pre-heat margin in heating system design: A review based upon published literature. Build. Serv. Eng. Res. Technol. 2001, 22, 255-260. [CrossRef]

48. Menezes, A.; Cripps, A.; Bouchlaghem, D.; Buswell, R. Predicted vs. actual energy performance of non-domestic buildings. Appl. Energy 2011, 97, 355-364. [CrossRef]

49. Djunaedy, E.; Van Den Wymelenberg, K.; Acker, B.; Thimmana, H. Oversizing of HVAC system: Signatures and penalties. Energy Build. 2011, 43, 468-475. [CrossRef]

50. Brand, M.; Svendsen, S. Renewable-based low-temperature district heating for existing buildings in various stages of refurbishment. Energy 2013, 62, 311-319. [CrossRef]

51. CIBSE. CIBSE Guide B1: Heating; CIBSE: London, UK, 2016.

52. Østergaard, D.S.; Svendsen, S. Theoretical overview of heating power and necessary heating supply temperatures in typical Danish single-family houses from the 1900s. Energy Build. 2016, 126, 375-383. [CrossRef]

53. Ovchinnikov, P.; Borodinecs, A.; Millers, R. Utilization potential of low temperature hydronic space heating systems in Russia. $J$ Build Eng. 2017, 13, 1-10. [CrossRef]

54. Hasan, A.; Kurnitski, J.; Jokiranta, K. A combined low temperature water heating system consisting of radiators and floor heating. Energy Build. 2009, 41, 470-479. [CrossRef]

55. Wang, Q.; PLoskić, A.; Song, X.; Holmberg, S. Ventilation heat recovery jointed low-temperature heating in retrofitting-An investigation of energy conservation, environmental impacts and indoor air quality in Swedish multifamily houses. Energy Build. 2016, 121, 250-264. [CrossRef]

56. CIBSE. CIBSE Weather Data Sets; CIBSE: London, UK, 2016.

57. Christenson, M.; Manz, H.; Gyalistras, D. Climate warming impact on degree-days and building energy demand in Switzerland. Energy Convers. Manag. 2006, 47, 671-686. [CrossRef]

58. Levermore, G.; Courtney, R.; Watkins, R.; Cheung, H.K.W.; Parkinson, J.B.; Laycock, P.; Natarajan, S.; Nikolopoulou, M.-H.; Mcgilligan, C.; Muneer, T.; et al. Deriving and Using Future Weather Data for Building Design from UK Climate Change Projections-An Overview of the COPSE Project. 2014. Available online: https:/ / researchdata.bath.ac.uk/186/1/COPSE-final. pdf (accessed on 27 October 2021).

59. Bordass, B.; Cohen, R.; Standeven, M.; Leaman, A. Assessing building performance in use 3: Energy performance of the Probe buildings. Build. Res. Inf. 2001, 29, 114-128. [CrossRef]

60. Newton, P.; Keith, H.; Drogemuller, R. Technology, Design and Process Innovation in the Built Environment; Spon Press: Abingdon, UK, 2009; Volume 4.

61. Millar, M.-A.; Burnside, N. An investigation into the limitations of low temperature district heating on traditional tenement buildings in Scotland. Energies 2019, 12, 1-17. [CrossRef]

62. BEIS. Domestic Heat Distribution Systems: Evidence Gathering. Final Report. 2021. Available online: https://assets.publishing service.gov.uk/government/uploads/system/uploads/attachment_data/file/976020/beis-dhds-executive-summary___.pdf (accessed on 27 October 2021).

63. Rønneseth, Ø.; Sandberg, N.H.; Sartori, I. Is it possible to supply Norwegian apartment blocks with 4th generation district heating? Energies 2019, 12, 941. [CrossRef]

64. Jones, D.; Eckert, C. Overdesign in building services: The hidden energy use. In Proceedings of the 21st International Conference on Engineering Design, Vancouver, BC, Canada, 21-25 August 2017.

65. Østergaard, D.S.; Svendsen, S. Costs and benefits of preparing existing Danish buildings for low-temperature district heating. Energy 2019, 176, 718-727. [CrossRef]

66. Geyer, R.; Krail, J.; Leitner, B.; Schmidt, R.-R.; Paolo, L. Energy-economic assessment of reduced district heating system temperatures. Smart Energy 2021, 2, 100011. [CrossRef]

67. Potter, I.N.; Jones, T.J.; Booth, W.B. Air Leakage of Office Buildings_Technical Note TN8/95; BSRIA: Bracknell, UK, 1995. Available online: https:/ / www.aivc.org/sites/default/files/airbase_8939.pdf (accessed on 27 October 2021).

68. Van Dronkelaar, C.; Dowson, M.; Burman, E.; Spataru, C.; Mumovic, D. A Review of the Regulatory Energy Performance Gap and Its Underlying Causes in Non-domestic Buildings. Front. Mech. Eng. 2016, 1, 17. [CrossRef]

69. BPIE. Europe's Buildings under the Microscope; Buildings Performance Institute Europe (BPIE): Brussels, Belgium, 2011. Available online: http:/ /bpie.eu/wp-content/uploads/2015/10/HR_EU_B_under_microscope_study.pdf (accessed on 20 October 2021).

70. Shi, X.; Si, B.; Zhao, J.; Tian, Z.; Wang, C.; Jin, X.; Zhou, X. Magnitude, causes, and solutions of the performance gap of buildings: A review. Sustainability 2019, 11, 1-21. [CrossRef]

71. Jones, D.A.; Eckert, C.M.; Gericke, K. Margins leading to over-capacity. Proc. Int. Des. Conf. Des. 2018, 2, 781-2792. 
72. Cohen, R.; Standeven, M.; Bordass, B.; Bordass, W.; Leaman, A. Probe Strategic Review 1999 Final Report 1: Review of the Probe Process. Available online: https://www.usablebuildings.co.uk/UsableBuildings/Unprotected/Probe/ProbePDFs/SR1.pdf (accessed on 20 October 2021).

73. BRE. Appendix S: Reduced Data SAP for Existing Dwellings. The Government's Standard Assessment Procedure for Energy Rating of Dwellings; BRE: Bracknell, UK, 2017. Available online: https://www.bre.co.uk/filelibrary/SAP/2012/RdSAP-9.93/RdSAP_2012 9.93.pdf (accessed on 20 October 2021).

74. Bennett, G.; Elwell, C. Effect of boiler oversizing on efficiency: A dynamic simulation study. Build. Serv. Eng. Res. Technol. 2020, 41, 709-726. [CrossRef]

75. Østergaard, D.S.; Svendsen, S. Replacing critical radiators to increase the potential to use low-temperature district heating-A case study of 4 Danish single-family houses from the 1930s. Energy 2016, 110, 75-84. [CrossRef]

76. Tunzi, M.; Østergaard, D.S.; Svendsen, S.; Boukhanouf, R.; Cooper, E. Method to investigate and plan the application of low temperature district heating to existing hydraulic radiator systems in existing buildings. Energy 2016, 113, 413-421. Available online: http://orbit.dtu.dk/files/143898981/Revised_Manuscript_Unmarked_Michele_Tunzi_POST_PRINT.pdf (accessed on 20 October 2021). [CrossRef]

77. British Standard Institution (BSI). BS EN 442-2:2014 Radiators and Convectors Part 2: Test Methods and Rating; BSI: London, UK, 2014.

78. British Standard Institution (BSI). BS EN 442-1:2014 Radiators and Convectors Part 1: Technical Specifications and Requirements; BSI: London, UK, 2014.

79. Young, B.; Shiret, A.; Hayton, J.; Griffiths, W. Design of Low-Temperature Domestic Heating Systems; BRE: Bracknell, UK, 2014.

80. Mcintyre, D.A. Output of Radiators at Reduced Flow Rate. 1986. Available online: https://journals.sagepub.com/doi/10.1177/ 014362448600700206 (accessed on 20 October 2021).

81. Danish Standard. Danish Standard DS 469-Heating and Cooling Systems in Buildings; Danish Standard: Copenhagen, Denmark, 2013.

82. British Standard Institution (BSI). BS 3528-1977 Specification for Convection Type Space Heaters Operating with Steam or Hot Water; BSI: London, UK, 1977.

83. British Standard. BS 6880-2:1988 Low Temperature Hot Water Heating Systems of Output Greater than 45 kW; British Standard: London, UK, 1988.

84. CIBSE; ADE. Heat Networks: Code of Practice for the UK (CP1); CIBSE: London, UK, 2020.

85. Calisir, T.; Yazar, H.O.; Baskaya, S. Determination of the effects of different inlet-outlet locations and temperatures on PCCP panel radiator heat transfer and fluid flow characteristics. Int. J. Therm. Sci. 2017, 121, 322-335. [CrossRef]

86. Hall, F.; Greeno, R. Building Services Handbook. Brick Cladding to Timber Frame Construction, 9th ed.; Routledge: Abingdon, UK, 2017; Volume 1.

87. CIBSE. Non-Domestic Hot Water Heating Systems AM14; CIBSE: London, UK, 2010.

88. Ofgem. Balancing and Settlement Code Modifications P272 and P322; Ofgem: Glasgow, UK, 2016.

89. Guzzini, A.; Pellegrini, M.; Pelliconi, E.; Saccani, C. Low temperature district heating: An expert opinion survey. Energies 2020, 13, 810. [CrossRef]

90. Element Energy. Research on District Heating and Local Approaches to Heat Decarbonisation. A Study for the Committee on Climate Change. 2015. Available online: https:/ / www.theccc.org.uk/publication/element-energy-for-ccc-research-on-districtheating-and-local-approaches-to-heat-decarbonisation/ (accessed on 20 October 2021).

91. Werner, S. International review of district heating and cooling. Energy 2017, 137, 617-631. [CrossRef]

92. Buffa, S.; Cozzini, M.; D'Antoni, M.; Baratieri, M.; Fedrizzi, R. 5th generation district heating and cooling systems: A review of existing cases in Europe. Renew. Sustain. Energy Rev. 2019, 104, 504-522. Available online: https://linkinghub.elsevier.com/ retrieve/pii/S1364032118308608pdf (accessed on 20 October 2021). [CrossRef]

93. DECC (UK Gov). SAP 2009-The Government's Standard Assessment Procedure for Energy Rating of Dwellings. Energy 2009. Available online: http:/ / www.bre.co.uk/filelibrary/SAP/2009/SAP-2009_9-90.pdf (accessed on 20 October 2021).

94. BRE. SAP 2012—Standard Assessment Procedure for Energy Rating of Dwellings (SAP); BRE: Watford, UK, 2012.

95. BRE. SAP 10.0—The Government's Standard Assessment Procedure for Energy Rating of Dwellings; BRE: Watford, UK, 2018.

96. Wiltshire, R.; Williams, J.; Woods, P. A Technical Guide to District Heating. 2014. Available online: www.ihs.com (accessed on 23 July 2019).

97. Minister of Housing Communities and Local Government. The Future Buildings Standard: Consultation on changes to Part L and Part F of the Building Regulations. 2021. Available online: https://assets.publishing.service.gov.uk/ government/uploads/system/uploads/attachment_data/file/953718/Future_Buildings_Standard_consultation_document. pdf (accessed on 20 October 2021).

98. CIBSE; ADE. Heat Networks: Code of Practice for the UK (CP1); CIBSE: London, UK, 2015; pp. 1-131.

99. British Standard. BS 6880-1:1988 Low Temperature Hot Water Heating Systems of Output Greater than 45 kW; British Standard: London, UK, 1988.

100. UK Government-Department for Communities and Local Government. Energy Performance of Buildings Directive Article 8 Equivalence. 2012. Available online: https://www.gov.uk/government/publications/energy-performance-of-buildingsdirective-article-8-equivalence-uk-biennial-reports (accessed on 20 October 2021).

101. Liao, Z.; Swainson, M.; Dexter, A.L. On the control of heating systems in the UK. Build. Environ. 2005, 40, 343-351. [CrossRef] 
102. CIBSE. Cibse Guide H: Building Control Systems; CIBSE: London, UK, 2009.

103. Energy Saving Trust. Central Heating System Specifications (CHeSS) Year 2008 Contents. 2008. Available online: https: / / bpec.org.uk/downloads/CE51CHeSSWEBFINALJULY08.pdf (accessed on 20 October 2021).

104. HM Government. The Building Regulations 2002: Conservation of Fuel and Power in Dwellings-Approved Document Part L1B. 2002; pp. 1-54. Available online: http://webarchive.nationalarchives.gov.uk/20141202102454/http://planningportal.gov.uk/ uploads/br/BR_PDF_ADL1_2002.pdf (accessed on 20 October 2021).

105. Building Research Establishment. Evidence Gathering-Compensation and TPI Heating Controls. 2017; Volume 44. Available online: https://assets.publishing.service.gov.uk/government/uploads/system/uploads/attachment_data/file/648337/heatingcontrols-compensation-tpi-bre.pdf (accessed on 20 October 2021).

106. Energy Saving Trust. Thermostats and Controls; Energy Saving Trust: London, UK, 2021. Available online: http://www. energysavingtrust.org.uk/home-energy-efficiency/thermostats-and-controls (accessed on 20 October 2021).

107. Worcester. User Instructions: Gas-fired condensing combi appliance Greenstar 4000. 2020. Available online: file:// C:/Users / KTPASS \{\}1/AppData/Local/Temp/Greenstar_4000_Combi_Operating_Manual.pdf (accessed on 20 October 2021).

108. Viessmann. Operating Instructions \& User' s Information Manual. 2014. Available online: https://www.viessmann-us.com/ content/dam/vi-brands/CA/pdfs/doc/cpk/vitodens_100-wb1bc_oi.pdf/_jcr_content/renditions/original.media_file.inline. file/ file.pdf (accessed on 20 October 2021).

109. Ideal Boilers. User Guide. 2018. Available online: https://idealheating.com/uploads/documents/Esprit_Eco_User_Guide.pdf (accessed on 20 October 2021).

110. Vaillant. Operating Instructions for the Operator. Available online: https://www.vaillant.co.uk/downloads/product-manuals/ ecotec-plus-1/ecotec-plus-operating-instructions-1943259.pdf (accessed on 20 October 2021).

111. Heating and Hot Water Industry Council. Consumer Guide: Balancing the Central Heating System. Available online: https: / / www.hhic.org.uk/uploads/5ACCA2408554F.pdf (accessed on 20 October 2021).

112. Petitjean, R. Balancing of Radiator Systems, 3rd ed.; Tour and Andersson AB: Lund, Sweden, 2003.

113. Eskima Design Ltd. Balancing Procedure. 2018. Available online: http://www.eskimodesign.co.uk/wp-content/uploads/2011 /11/Technical-help-radiator-balancing1.pdf (accessed on 20 October 2021).

114. Drayton Shneider Electric. Commissioning Instructions. Available online: https://www.draytoncontrols.co.uk/sites/default/ files/D34-11TRV comissioning.pdf (accessed on 20 October 2021).

115. Stelrad Radiator Group. Balancing a System. 2019. Available online: https://www.stelrad.com/wp-content/uploads/2019/06/ Balancing-a-system.pdf (accessed on 20 October 2021).

116. Heat Pump Association. Heat Emitter Follow Up-Survey Results Summary; Heat Pump Association: Reading, UK, 2021.

117. BEIS. HEAT IN BUILDINGS-The Future of Heat: Domestic Buildings. 2016. Available online: https://www.gov.uk/ government/uploads/system/uploads / attachment_data/file/575299/Heat_in_Buildings_consultation_document_v1.pdf (accessed on 20 October 2021).

118. Ahern, C.; Norton, B. Energy savings across EU domestic building stock by optimizing hydraulic distribution in domestic space heating systems. Energy Build. 2015, 91, 199-209. [CrossRef]

119. DECC. How Heating Controls Affect Domestic Energy Demand: A Rapid Evidence Assessment; DECC: London, UK, 2014. Available online: https://assets.publishing.service.gov.uk/government/uploads/system/uploads/attachment_data/file/277552/FINALHow_ heating_controls_affect_domestic_energy_demand_-_A_Rapid_Evidence_Assessment.pdf (accessed on 20 October 2021).

120. Patronen, J.; Kaura, E.; Torvestad, C. Nordic Heating and Cooling: Nordic Approach to EU's Heating and Cooling Strategy; Nordic Council of Ministers: Copenhagen, Denmark, 2017; p. 113. Available online: http://norden.diva-portal.org/smash/get/diva2: 1098961/FULLTEXT01.pdf (accessed on 20 October 2021).

121. Averfalk, H.; Benakopoulos, T.; Best, I.; Dammel, F.; Engel, C.; Geyer, R.; Gudmundsson, O.; Lygnerud, K.; Nord, N.; Oltmanns, J.; et al. Implementation of Low-Temperature District Heating Systems; IEA DHC: Frankfurt am Main, Germany, 2021. Available online: https: / / www.iea-dhc.org/the-research/annexes/2017-2021-annex-ts2 (accessed on 20 October 2021).

122. Frederiksen, S.; Werner, S. District Heating and Cooling; Studentlitteratur: Lund, Sweden, 2017.

123. Boverkets. Boverkets Nybyggnadsregler BFS 1988:18 NR 1. 1988. Available online: https://www.boverket.se/contentassets/63 9573ac3ef44319b4752cd302f0a053/nybyggnadsregler-nr-1.pdf (accessed on 20 October 2021).

124. Jangsten, M.; Kensby, J.; Dalenbäck, J.O.; Trüschel, A. Survey of radiator temperatures in buildings supplied by district heating. Energy 2017, 137, 292-301. [CrossRef]

125. Svensk Fjärrvärme. Utförande Och Installation. 2014. Available online: http://www.svenskenergi.se/Vi-erbjuder/ Webbshop / Fjarrvarme/Fjarrvarme1/Tekniska-bestammelser/F101-Fjarrvarmecentralen---Utforande-och-installation / (accessed on 8 February 2021).

126. Tol, H.I.; Desmedt, J.; Salenbien, R. A novel demand-responsive control strategy for district heating systems, featuring return temperature reduction. Energy Built Environ. 2021, 2, 105-125. [CrossRef]

127. Li, H.; Svendsen, S.; Gudmundsson, O.; Kuosa, M.; Rämä, M.; Sipilä, K.; Biesl, M.; Broydo, M.; Stehle, M.; Pesch, R.; et al. Future Low Temperature District Heating Design Guidebook. 2017. Available online: https://core.ac.uk/download/pdf/154332407.pdf (accessed on 20 October 2021).

128. Kristensen, M.H.; Petersen, S. District heating energy efficiency of Danish building typologies. Energy Build. 2021, $231,110602$. [CrossRef] 
129. Li, H.; Nord, N. Transition to the 4th generation district heating-possibilities, bottlenecks, and challenges. Energy Procedia 2018, 149, 483-498. [CrossRef]

130. Gadd, H.; Werner, S. Achieving low return temperatures from district heating substations. Appl. Energy 2014, 136, 59-67. [CrossRef]

131. European Union. Directive 2010/31/EU of the European Parliament and of the Council of 19 May 2010 on the energy performance of buildings. Off. J. Eur. Union 2010, 13-35. Available online: https://eur-lex.europa.eu/legal-content/EN/TXT/PDF/?uri= CELEX:32010L0031\&from $=$ en (accessed on 20 October 2021).

132. Ziemele, J.; Pakere, I.; Chernovska, L.; Blumberga, D. Lowering Temperature Regime in District Heating Network for Existing Building Stock. Chem. Eng. 2016, 52, 709-714.

133. Werner, S. District heating and cooling in Sweden. Energy 2017, 126, 419-429. [CrossRef]

134. Dalla Rosa, A. The Development of a New District Heating Concept: Network Design and Optimization for Integrating Energy Conservation and Renewable Energy Use in Energy Sustainable Communities; DTU: Lyngby, Denmark, 2012; Volume 269. Available online: https://orbit.dtu.dk/en/publications/the-development-of-a-new-district-heating-concept-network-design(accessed on 20 October 2021).

135. Werner, S.; Lund, H.; Van Mathiesen, B. Progress and results from the $4 \mathrm{DH}$ research centre. In Proceedings of the 14th International Symposium on District Heating and Cooling, Stockholm, Sweden, 7-9 September 2014; pp. 302-307.

136. Tereshchenko, T.; Nord, N. Future Trends in District Heating Development. Curr. Sustain. Energy Rep. 2018, 5, 172-180. [CrossRef]

137. Sernhed, K.; Lygnerud, K.; Werner, S. Synthesis of recent Swedish district heating research. Energy 2018, 151, 126-132. [CrossRef]

138. Difs, K.; Bennstam, M.; Trygg, L.; Nordenstam, L. Energy conservation measures in buildings heated by district heating-A local energy system perspective. Energy 2010, 35, 3194-3203. [CrossRef]

139. Åberg, M.; Henning, D. Optimisation of a Swedish district heating system with reduced heat demand due to energy efficiency measures in residential buildings. Energy Policy 2011, 39, 7839-7852. [CrossRef]

140. Dalla Rosa, A.; Christensen, J.E. Low-energy district heating in energy-efficient building areas. Energy 2011, 36, 6890-6899. [CrossRef]

141. Connolly, D.; Lund, H.; Mathiesen, B.; Werner, S.; Möller, B.; Persson, U.; Boermans, T.; Trier, D.; Østergaard, P.A.; Nielsen, S. Heat Roadmap Europe: Combining district heating with heat savings to decarbonise the EU energy system. Energy Policy 2014, 65, 475-489. [CrossRef]

142. British Standard Institution (BSI). BS EN 1264-3:2021 Water Based Surface Embedded Heating and Cooling Systems-Part3: Dimensioning; BSI: London, UK, 2009.

143. Rämä, M.; Sipilä, K. Transition to low temperature distribution in existing systems. Energy Procedia 2017, 116, 58-68. [CrossRef]

144. Liu, Z.; Xu, W.; Li, Z.; Zhang, L.; Li, J.; Li, A.; Feng, A. Research on heating performance of heating radiator at low temperature. J. Build. Eng. 2020, 36, 102016. [CrossRef]

145. Tol, H.İ. Improved space-heating radiator model: Focus on set-back operation, radiator over-dimensioning, and add-on fans. Build. Simul. 2020, 13, 317-334. [CrossRef]

146. IRENA. Integrating Low-Temperature Renewables in District Energy Systems: Guidelines for Policy Makers. 2021. Available online: https://irena.org/publications/2021/March/Integrating-low-temperature-renewables-in-district-energy-systems (accessed on 20 October 2021).

147. Østergaard, D.S.; Paulsen, O.; Sørensen, I.B.; Svendsen, S. Test and evaluation of a method to identify heating system malfunctions by using information from electronic heat cost allocators. Energy Build. 2019, 184, 152-162. [CrossRef]

148. Averfalk, H.; Werner, S.; Felsmann, C.; Rühling, K.; Wiltshire, R.; Svendsen, S.; Hongwei, L.; Faessler, J.; Mermoud, F.; Quiquerez, L. Transformation Roadmap from High to Low Temperature District Heating Systems. 2017. Available online: https://archiveouverte.unige.ch/unige:96252 (accessed on 20 October 2021).

149. Østergaard, D.S.; Svendsen, S. Experience from a practical test of low-temperature district heating for space heating in five Danish single-family houses from the 1930s. Energy 2018, 159, 569-578. [CrossRef]

150. Schmidt, D.; Kallert, A.; Blesl, M.; Svendsen, S.; Li, H.; Nord, N. Low Temperature District Heating for Future Energy Systems. Energy Procedia 2017, 106, 26-38. [CrossRef]

151. Benakopoulos, T.; Salenbien, R.; Vanhoudt, D.; Svendsen, S. Improved control of radiator heating systems with thermostatic radiator valves without pre-setting function. Energies 2019, 12, 3215. [CrossRef]

152. Averfalk, H.; Werner, S. Economic benefits of fourth generation district heating. Energy 2020, 193, 116727. [CrossRef]

153. Chaudry, M.; Abeysekera, M.; Hosseini, S.H.R.; Jenkins, N.; Wu, J. Uncertainties in decarbonising heat in the UK. Energy Policy 2015, 87, 623-640. [CrossRef]

154. Galindo, F.M.; Lacan, C.R.; Gahrs, U.; Aumaitre, V. Efficient District Heating and Cooling Markets in the EU: Case Studies Analysis, Replicable Key Success Factors and Potential Policy Implications; European Commission: Brussels, Belgium, 2016.

155. FVB District Energy. Heat Tariff Structure to Reduce District Heating Return Temperature and Peak Demand; FVB District Energy: Reading, UK, 2019.

156. Volkova, A.; Mašatin, V.; Siirde, A. Methodology for evaluating the transition process dynamics towards 4 th generation district heating networks. Energy 2018, 150, 253-261. [CrossRef]

157. British Standard Institution (BSI). EN 15251:2007 Indoor Environmental Input Parameters for Design and Assessment of Energy Performance of Buildings Addressing Indoor Air Quality, Thermal Environment, Lighting and Acoustics; BSI: London, UK, 2008. 
158. Olesen, B.W.; Wang, H.; Kazanci, O.B.; Coakley, D.; Alle, N.K.; Lyngby, K. The effect of room temperature control by air-or operative temperature on thermal comfort and energy use. In Proceedings of the 16 IPBSA Conference, Rome, Italy, 2-4 September 2019; pp. 2086-2093.

159. Dawe, M.; Raftery, P.; Woolley, J.; Schiavon, S.; Bauman, F. Comparison of mean radiant and air temperatures in mechanicallyconditioned commercial buildings from over 200,000 field and laboratory measurements. Energy Build. 2020, $206,109582$. [CrossRef]

160. DTU Byg Institut for Byggeri og Anlæg. CO2-Reductions in Low-Energy Buildings and Communities by Implementation of LowTemperature District Heating Systems; DTU: Lynbgy, Denmark, 2011. Available online: https:/ / www.osti.gov/etdeweb/servlets / purl/1032896 (accessed on 20 October 2021).

161. Health and Safety Executive. Part 2: The Control of Legionella Bacteria in Hot and Cold Water Systems. Legionnaires' Disease. Technical Guidance. 2014. Available online: https://www.hse.gov.uk/pubns/priced/hsg274part2.pdf (accessed on 20 October 2021).

162. Tofield, B. Delivering a Low-Energy Low Energy Building. 2012. Available online: http:/ / archive.northsearegion.eu/files/repository/ 20140331180312_BuildwithCaReResearchReport-DeliveringaLow-EnergyBuildingOct2012.pdf (accessed on 20 October 2021).

163. Nord, N.; Ingebretsen, M.E.; Tryggestad, I.S. Possibilities for Transition of Existing Residential Buildings to Low Temperature District Heating System in Norway. In Proceedings of the 12th REHVAWorld Congress, Aalborg, Denmark, $22-25$ May 2016.

164. Olsen, P.K.; Christiansen, C.H.; Hofmeister, M.; Svendsen, S.; Thorsen, J.-E. Guidelines for Low-Temperature District Heating. 2014. Available online: https:/ / www.danskfjernvarme.dk/groen-energi/projekter/lavtemperaturfjernvarme (accessed on 20 October 2021).

165. Ruyssevelt, P.; Min Hong, S. Scottish Energy Officers Energy Benchmarking Exercise Final Report. Unpublished work, 2019.

166. Aksoezen, M.; Daniel, M.; Hassler, U.; Kohler, N. Building Age as an Indicator for Energy Consumption. 2015. Available online: https:/ / doi.org/10.1016/j.enbuild.2014.10.074 (accessed on 20 October 2021).

167. European Commission. Energy Efficiency Plan. 2011. Available online: https:/ / eur-lex.europa.eu/LexUriServ/LexUriServ.do? uri=COM:2011:0109:FIN:EN:PDF (accessed on 20 October 2021).

168. Delta, E.E. Delta-ee Report for SGN The Potential for a Novel Fuel Cell-Heat Pump Heating System. 2016. Available online: https: / www.delta-ee.com/downloads/783-the-potential-for-a-novel-fuel-cell-heat-pump-heating-system.html (accessed on 20 October 2021).

169. Harrestrup, M.; Svendsen, S. Changes in heat load profile of typical Danish multi-storey buildings when energy-renovated and supplied with low-temperature district heating. In Proceedings of the 4th International Conference on Renewable Energy Sources \& Energy Efficiency, Nicosia, Cyprus, 6-7 June 2013; pp. 232-247.

170. BuroHappold Engineering. Connecting Existing Buildings to District Heating Networks. 2016. Available online: https://www. usdn.org/uploads/cms/documents /161214_-_connecting_existing_buildings_to_dhns_-_technical_report_00.pdf (accessed on 20 October 2021).

171. Wang, Q.; PLoskić, A.; Holmberg, S. Retrofitting with low-temperature heating to achieve energy-demand savings and thermal comfort. Energy Build. 2015, 109, 217-229. [CrossRef]

172. Hesaraki, A.; PLoskic, A.; Holmberg, S. Integrating low-temperature heating systems into energy efficient buildings. Energy Procedia 2015, 78, 3043-3048. [CrossRef] 